\title{
Stature Estimation from the Hand Length: Testing Cross-Population Methods
}

\author{
Pavlína Ingrová $^{1}$ - Miroslav Králík ${ }^{1}$ - Věra Bártová ${ }^{1}$ - Martin Čuta ${ }^{1}$ - Pavel Grasgruber $^{2}$ - \\ Dominik Bokůvka ${ }^{3}$ \\ 1 Laboratory of Morphology and Forensic Anthropology (LaMorFA), Department of Anthropology, Faculty of Science, \\ Masaryk University, Kotlářská 2, 61137 Brno, Czech Republic \\ 2 Department of Athletics, Swimming and Outdoor Sports, Faculty of Sports Studies, Masaryk University, \\ Kamenice 753/5, 62500 Brno, Czech Republic \\ 3 Department of Sports, Faculty of Sports Studies, Masaryk University, Kamenice 753/5, 62500 Brno, Czech Republic
}

Received 6 ${ }^{\text {th }}$ March 2019; accepted 29 ${ }^{\text {th }}$ April 2019

\section{ODHAD VÝŠKY POSTAVY Z DÉLKY RUKY: TESTOVÁNÍ TRANSPOPULAČNÍCH METOD}

ABSTRAKT Délka ruky je vhodným tělesným rozměrem pro odhad výšky postavy ve forenzní antropologii. Takový odhad výšky postavy je však vždy ohrožen populační specifitou běžně užívaných regresních rovnic vypočítaných metodou nejmenších čtverců. Na základě dřive publikovaných statistických parametrů (průměrné hodnoty délky ruky a výšky postavy, regresní koeficienty) z 87 publikovaných studií (212 populačních vzorků) jsme metodami průměrování regresních koeficientů a redukované hlavní osy vytvořili soubor nových transpopulačních rovnic pro odhad výšky postavy z délky ruky. Následně jsme ověřovali přesnost odhadů z těchto nových rovnic na pěti referenčních vzorcích z české, slovenské a bosenské populace a porovnali jejich výsledky s výsledky modelu metody nejmenších čtverců, vyvinuté na českém vzorku. Výsledky ukázaly, že navržené transpopulační rovnice nejsou vhodné pro odhad výšky postavy z délky ruky, pokud nejsou omezeny např. na geograficky užší populační skupinu (v naší studii Evropané slovanského původu). Principiálně obdobné konsekvence doporučujeme zvážit také u odhadů u délek kostí při hodnocení výšky postavy na základě forenzních nálezů skeletu.

KLÍČOVÁ SLOVA délka ruky; výška postavy; odhad výšky postavy; regresní rovnice; regresní metoda redukované hlavní osy; průměrné regresní koeficienty

ABSTRACT It has been established that hand length is a suitable parameter for stature estimation in forensic anthropology. However, such estimation is always compromised by population specificity of ordinary regression equations. Based on previously published statistical parameters (average values, regression coefficients) from 87 studies (212 different samples) available in literature, we developed a set of new crosspopulation equations for estimation of body height from the hand length (Reduced Major Axis Models, Average Regression Models). Subsequently, we tested the accuracy and preciseness of these new equations on five testing samples of primary measurements originating from Czech, Slovak and Bosnian populations and compared the height estimates with the results of traditional Least Squares methods developed on a Czech sample. The results showed that cross-population based models are not suitable for body height estimation from hand length unless they are limited to a narrower geographically confined population group (in our study Europeans of Slavic origin). We propose considering principally similar consequences when estimating the body height from a bone length in forensic skeletal cases.

KEY WORDS hand length; body height; stature estimation; regression equations; Reduced Major Axis regression method; average regression coefficients 


\section{INTRODUCTION}

Stature estimation represents an important part of biological profiling in the process of anthropological analysis in forensic identification (Jasuja - Singh 2004; Krishan - Sharma 2007; Goswami et al. 2016) or other osteological applications (Bedić et al. 2013; Polcerová - Králík 2016). In forensic investigation, occasionally, except for hand prints (Krishan et al. 2015; Paulis 2015; Zulkifly et al. 2018), body height might be estimated from amputated limbs or their parts (hands, fingers, feet) obtained after natural disasters (earthquake, tsunami), terroristic attacks, accidents (airplane crash, wars), murders etc. (Jasuja - Singh 2004; Chikhalkar et al. 2010; Krishan et al. 2010; Pal et al. 2016).

Stature estimation is usually based on known relation between body height and size of a body part used for estimation (Özaslan et al. 2012; Nor et al. 2013; Rexhepi - Brestovci 2015; Ahmed and Taha 2016; Mahakizadeh et al. 2016; Brits et al. 2017; Kyllonen et al. 2017; Torimitsu et al. 2017; Howley et al. 2018; Reynolds et al. 2018) including hands found for example on a crime scene. Within the hand measurements, hand width and hand length are the most used parameters for estimation of body height (Krishan - Sharma 2007; Agnihotri et al. 2008; Rastogi et al. 2008; Chikhalkar et al. 2010; Özaslan et al. 2012; Ahmed 2013; Jee - Yun 2015; Paulis 2015; Uhrová et al. 2015). Various length measurements of the hand are more reliable for stature estimation than hand width measurements and circumferences (Akhlaghi et al. 2012; Özaslan et al. 2012; Ahmed 2013; Jee - Yun 2015; Pal et al. 2016). Jee and Yun (2015) stated that the most relevant for body height estimation is hand length. From the most frequently measured hand dimensions the hand length correlates the most with body height (Özaslan et al. 2006, 2012; Krishan - Sharma 2007; Habib - Kamal 2010; Akhlaghi et al. 2012; Ishak et al. 2012; Ahmed 2013; Paulis 2015; Uhrová et al. 2015; Jee and Yun 2016; Pal et al. 2016). Standard error of estimate (SEE) of equations for stature estimation from hand length is mostly lower than SEE of other dimensions of the hand (Krishan - Sharma 2007; Rastogi et al. 2008; Habib Kamal 2010; Ishak et al. 2012; Özaslan et al. 2012; Ahmed 2013; Jee - Yun 2015; Uhrová et al. 2015; Pal et al. 2016). SEEs from the hand measurements are comparable or only slightly higher with SEEs computed from long bones that are obviously used in forensic anthropology (Dayal et al. 2008; Mahakkanukrauh et al. 2011), and comparable with errors of estimates from other body measurements (Özaslan et al. 2003, 2006; Mahakizadeh et al. 2016). It follows that hand length is a suitable parameter for estimation of body height.

Sometimes the hand length cannot be measured due to damage to the hand or missing fingers. Then, other hand measurements are used for estimation of body height, e.g. the width of the wrist (Özaslan et al. 2012; Ahmed 2013; Jee - Yun 2015), finger length (Akhlaghi et al. 2012; Ishak et al. 2012; Krishan et al. 2012; Sen et al. 2014; Jee - Yun 2015; Pal et al. 2016), length of individual phalanges (Jasuja - Singh 2004; Habib Kamal 2010; Jee - Yun 2015; Paulis 2015), palm length (Ishak et al. 2012; Jee - Yun 2015; Pal et al. 2016), circumference of fingers, wrist circumference, and palm circumference (Jee Yun 2015). Estimation of body height from these measurements is less accurate than estimation from the hand length. Therefore, when different hand measures are available for estimation of body height, hand length is the preferred option (Jee - Yun 2015).

We can add that also whole handprints, fingerprints (Ishak et al. 2012; Paulis 2015; Moorthy - Yin 2016) and epidermal ridge breadth or ridge density from fingerprints were used for stature estimation (Cummins et al. 1941; Kamp et al. 1999; Mundorff et al. 2014). For the sake of completeness, relationships of the body height with some hand proportions have been found, e.g. ratio between the length of the 2 nd and 4 th finger, but correlations are low and differ between studies (Rahman et al. 2005; Ibegbu et al. 2012; Ranson et al. 2015). From the methodological point of view, the most frequently applied approach to the stature estimation from the body parts was a simple linear regression based on the least squares (LS) criterion for minimizing residual variance. The estimated variable (dependent variable plotted on y-axis) is usually the height and it is estimated from the independent variable (plotted on the $\mathrm{x}$-axis) which is a measurement on a body part (here mostly hand length). This procedure represents the most accurate unbiased linear estimation of the dependent variable (body height). This is true, however, only when applied just to the original sample, i.e. the one on which the linear regression equation was calculated. Any application to another sample can be seriously flawed and the estimates might be practically inapplicable since errors can reach tens of centimeters (Sjøvold 1990; Malina 1994; Özaslan et al. 2006, 2012; Raxter et al. 2008; Duyar - Pelin 2010; Zeman - Králík 2012a; Uhrová et al. 2015).

In skeletal samples, a cross-population method for stature estimation was developed by Sjøvold (1990), who applied the method of Reduced Major Axis ("organic correlation") to population mean values (Rösing 1988) and the resulting regression equations were relatively "population-free" (Zeman - Králík 2012b). The resulting estimates are more accurate when applied to any case regardless of population, however, at the cost of lower precision comparing to a LS regression equation based on an appropriate population sample. Since population origins can be rarely known in cases of separated body parts similar population-free method might be probably useful also for the stature estimations from the hand measurements. To our best knowledge, so far, no such method has been developed.

\section{GOALS OF THE STUDY}

The main objectives of the study were to develop a crosspopulation $\operatorname{method}(\mathrm{s})$ for the estimation of human stature from the hand length by combining published data, test the method(s) to several empirically recorded samples of the European populations and to compare the estimates with estimates based on traditional LS regression methods. 


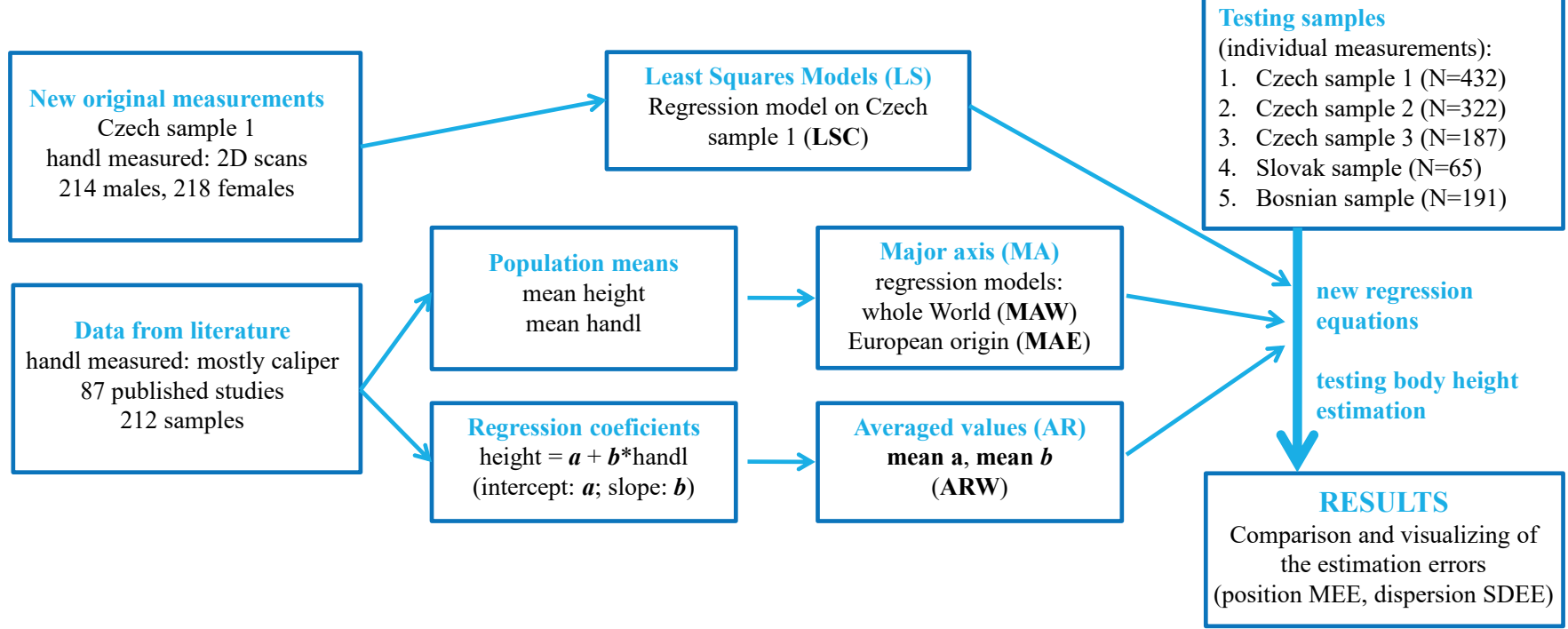

Fig. 1 Scheme of the study; height - body height, handl - hand length

\section{MATERIALS AND METHODS}

The testing strategy of our study (Fig. 1) was based on the following procedures. The first was searching literature for studies focused on stature estimation from the hand length and with secondary data (mean values and/or regression parameters) available for our computations of cross-population methods. The second were new original measurements for development of new population specific method. The third was testing new methods on testing samples (newly measured data or re-used from previous studies).

Resources for this study included several types of data:

\section{A. Published literature sources}

The first data source represented published studies addressing the relationship between the hand length and body height. Literature resources were searched in scientific portals, databases and repositories, including Science Direct, NCBI, ResearchGate, Google Scholar and others. We collected 87 published studies with 212 different samples included (when divided by sex and body side). From these studies we extracted population statistical parameters for mean values of the body height and the hand length. In the majority of the studies, body height was measured by means of standard anthropometric devices (anthropometer) and the hand length was mostly measured directly on hands by means of sliding calipers. At the same time, values for regression coefficients of the body height on the hand length were recorded, specifically intercept and slope of the regression line (LS regression). Some of the samples offered mean values, some offered population parameters and some both types of the secondary data. Since different measurement units were used in some studies, we also converted units of all studies to millimeters. Secondary data of published population parameters were used for constructing/developing cross-population models/equations for stature estimation from the hand length. The whole table of the applied population samples is available in the Appendix 1 and 2, including references.

\section{B. Czech population sample - new measurements}

The second source of data represented individual data of body height and hand length measured anew on a Czech population sample collected in years 2012 - 2016. This sample included 432 healthy young adults (214 males, 218 females, mostly university students) ranging from 17 to 35 years of age. Hand length was measured on images from a 2D desktop document scanner. A part of the sample was previously used in studies of the main authors (Ingrová et al. 2017). Czech sample 1 simultaneously represents testing sample 1 (see below). We used this sample for constructing new Least Squares regression models for stature estimation from the hand length.

\section{Testing samples}

The testing samples represented measured body height and hand length data acquired from 5 samples of different nationalities:

Testing sample 1: Czech sample 1 was described above (B). Testing sample 2: Czech sample 2 included 322 young adults (161 males and 161 females) from Brno Growth Study (Bouchalová 1987) conducted in years 1961 1980 and ranging from 15.5 to 26 years of age. Hand length (on the right hands only) was measured directly on hands by means of caliper.

Testing sample 3: Czech sample 3 was represented by 187 secondary school students (90 males and 97 females) ranging from 15.6 to 19.9 years of age. Research took 


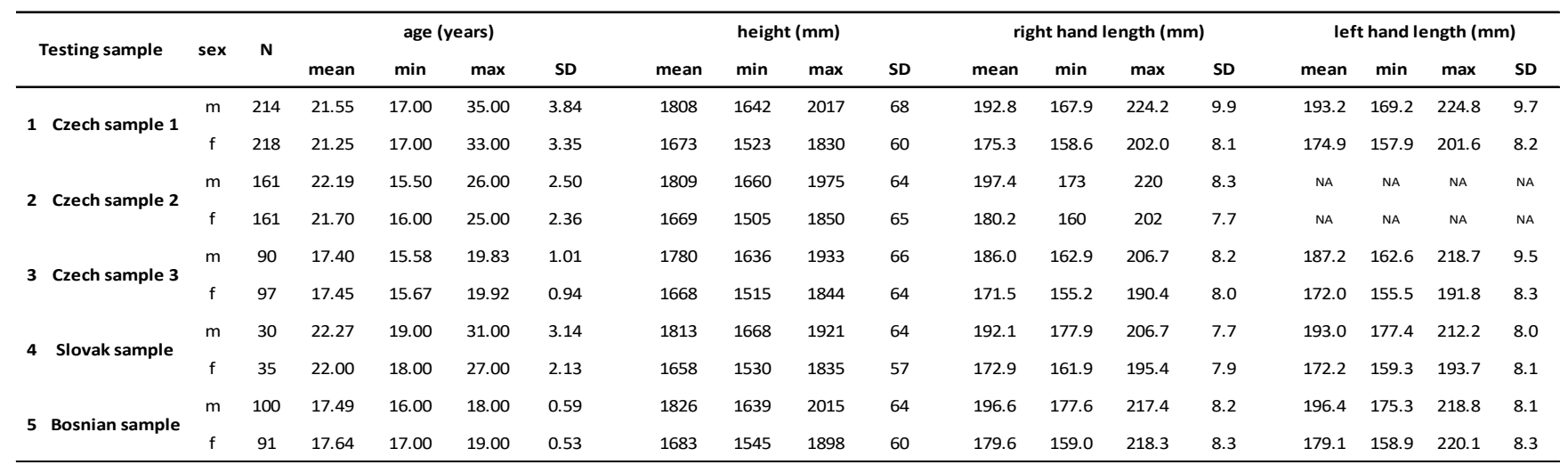

Table 1 Descriptive statistics of testing samples

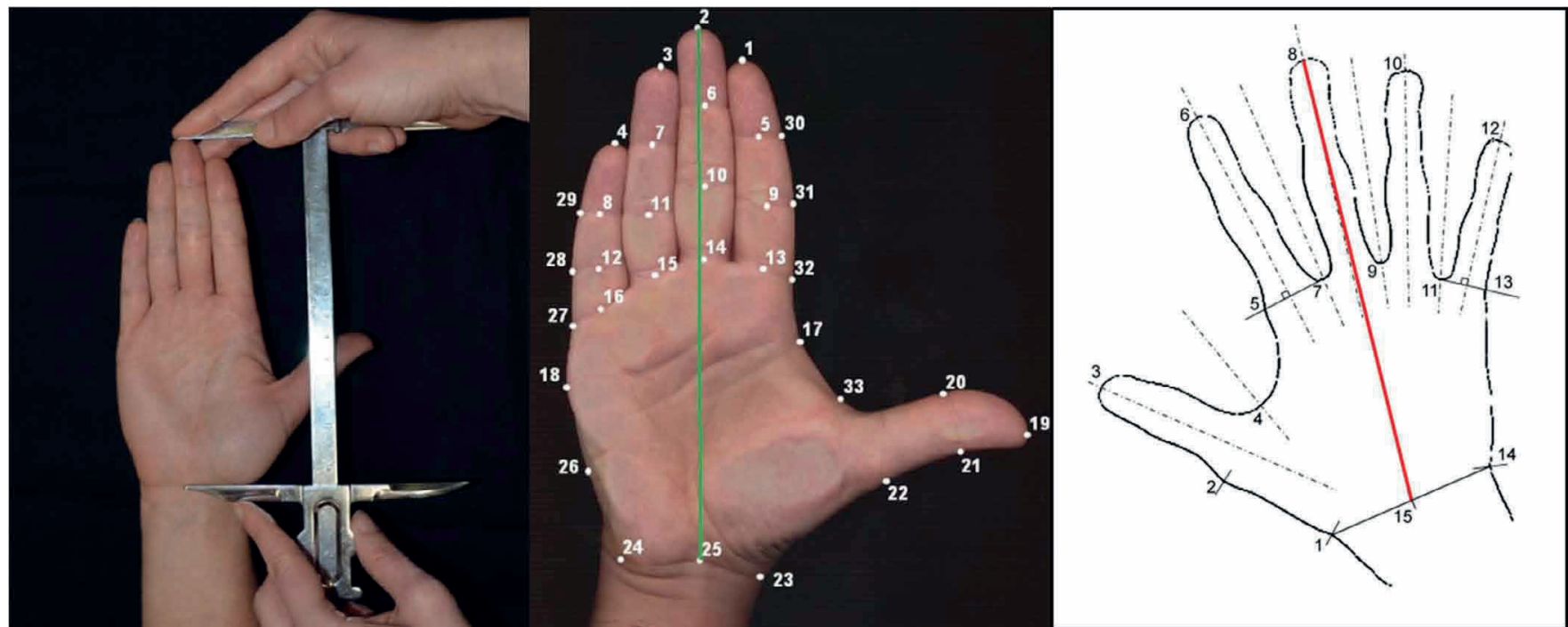

Fig. 2 Three methods of the hand length measurement used in this study. Direct measurement by using of sliding caliper (left), digital measurement on an image recorded by a $2 \mathrm{D}$ scanner (middle), and digital measurement on scanned hand contour on paper (right).

place in the year 2002. Hand length was measured on contours on paper.

Testing sample 4: Slovak sample was collected during present study organized in years 2012 - 2016. This sample included 65 healthy young adults ( 30 males and 35 females, mostly university students) ranging from 18 to 31 years of age. Hand length was measured on images from $2 \mathrm{D}$ scanner. A part of the sample was previously used in studies of the main authors (Ingrová et al. 2017). Testing sample 5: Bosnian sample included 191 high school students (100 males and 91 females measured in year 2016) ranging from 16 to 19 years of age. This research was part of the study by Grasgruber et al. (2017) and the hand length was measured on images from a 2D scanner.

Descriptive statistics of testing samples are shown in Table 1. Data of Czech sample 2 and 3 were available from the Archive of the Department of Anthropology, Faculty of Science, Masaryk University, Kotlářská 2, 61137 Brno, Czech Republic. Czech sample 1, Slovak and Bosnian samples were part of the project titled Size and Proportional Relationships of Hand
Morphology and the Human Body which was approved in 2012 by the Ethics Committee of Masaryk University in Brno. Participation in the research was anonymous and all participants signed informed consent. All data were expressed in millimeters. When the original published data used different units, we transferred the values also to millimeters to be comparable throughout the study.

\section{Methods for the Czech sample and testing samples}

\section{Height measurements}

Body height was measured in a standard position using a calibrated anthropometer with the precision of $1 \mathrm{~mm}$ according to Prokopec (1967).

\section{Hand measurements}

Hand length was measured using three methods: on the images from a 2D scanner, by means of a sliding caliper and on hand contours on paper (Fig. 2).

A. The caliper measurement: Hand length (on the right 
hand) was measured as the distance between the anthropometric landmarks interstylion and dactylion of the third finger by means of sliding caliper with the precision of $1 \mathrm{~mm}$ (Prokopec 1967). This method was used on the Czech sample 2.

B. Images from a $2 D$ scanner: both hands of each participant were scanned using the desktop scanner Canon CanoScan 4400F. Hands were scanned from palmar view in specific position: the fingers were pulled together with the thumb extended to its natural maximum. In these images, 33 landmarks were digitized in the tpsDig2 program (Rohlf 2013). From these landmarks were chosen landmarks 2 - a point corresponding to projection of dactylion of the third finger and landmark 25 - a point on a carpal flexion crease approximately in the middle of the wrist) were selected. From these two landmarks, the hand length was calculated in the PAST software (Hammer et al. 2001). This method was used in the Czech sample 1, Slovak and Bosnian samples.

C. Contours of hands: Hand shapes were recorded by outlining each hand with a regular pencil on a sheet of white paper. Contours were scanned by a $2 \mathrm{D}$ scanner and on the image landmarks were digitized in the computer program tpsDig2 (Rohlf, 2013). The hand length was measured as a distance between points 8 (cross-section between axis of the 3 rd finger and its distal contour) and 15 (midpoint between landmarks 1 a 14, landmark 1 represents the highest curvature of the contour corresponding to the space between processus styloideus radii and os trapezium, landmark 14 represents the highest curvature of the contour corresponding to the space between the proximal end of the 5 th metacarpal bone, os hamatum and os triquetrum. This method was used in the Czech sample 3.

\section{Computation of the newly developed equations}

\section{Reduced Major Axis Models (MA)}

For the first type of models, population mean values for stature and the hand length were used. Model II simple linear regression of the mean stature on the mean hand length was computed using the major axis method in the lmodel 2 R-package (Legendre 2014), analogously to Sjøvold's approach (Sjøvold 1990). The only difference was that we did not weight the average values from literature by the number of cases in the source original studies. The models were computed for each body side (right, left) and sex (males, females) separately, additionally also for males and females combined. Two versions of the MA model were developed: one for all samples available from the whole World (MAW model), and the second from the samples originated from Europe only (MAE model). Since all our testing samples originated from Europe, we were wondering if the estimates from MAE models will be better than those from MAW model. MAE models were based only on the previously published samples whereas our testing samples were not included within the source samples for the models.

\section{Average Regression Models (AR)}

Average Regression Models were computed from population values of intercept and slope of the Ordinary Least Square models for the relationship between body height and the hand length. It represented a simple way of meta-analysis of the regression parameters. Mean values were computed from all intercepts and all slopes from available studies. We computed the models from the data from the whole World (ARW model). Low number of samples from Europe did not allow us to developed separate model for Europe like in the case of the MA method. Then we used these averaged regression parameters for stature estimations of the testing samples. Since some published studies computed their regression models on mixed body sides or other specific combinations of hands (e.g. only dominant hands, i.e. mostly right but in a part left), along with the separate models for the right and left hands we also included groups computed from equations based on mixed hands. So, the models were computed for each sex (males, females) and body side (right, left, and mixed) separately, and also for the sexes combined.

\section{Least Squares Models (LSC)}

On the Czech sample 1 we computed a model II simple linear regression of the stature on the hand length using the Ordinary Least Squares method in the R-package Imodel2 (Legendre 2014). The models (LSC model) were computed separately for each sex and body side, as well as for sexes combined.

\section{Testing procedures}

The newly proposed equations/models were tested on the testing samples specified above. We computed the estimation of body height for each subject included in the testing samples and, subsequently, calculated the differences between true (recorded/documented) heights and the estimates - errors of estimates (see Note below). Each single/ individual error of estimate (EE) represented a difference between estimated and true height for an individual, i.e. an estimate minus the respective true value. Then, a positive value of EE signified an overestimation and the negative value of the EE signified an underestimation. For each combination of a model/method and a testing sample we calculated mean error of estimates (MEE) representing systematic average difference from zero (systematic shift of all values to positive or negative side) and standard deviation of errors of estimate (SDEE) representing an indicator of dispersion of individual estimates around MEE. The differences in errors between the methods were visualized, analyzed and discussed. Technical note: usually standard error of estimate is used for expression of the "quality" of a prediction from a regression model. The disadvantage of SEE is that it is based on the sum of squared differences between true and predicted values which lead to removing the sign of disagreement, i.e. overestimations are mixed with underestimations. Therefore, we worked directly with the differences (EE) and their basic descriptive statistics. 


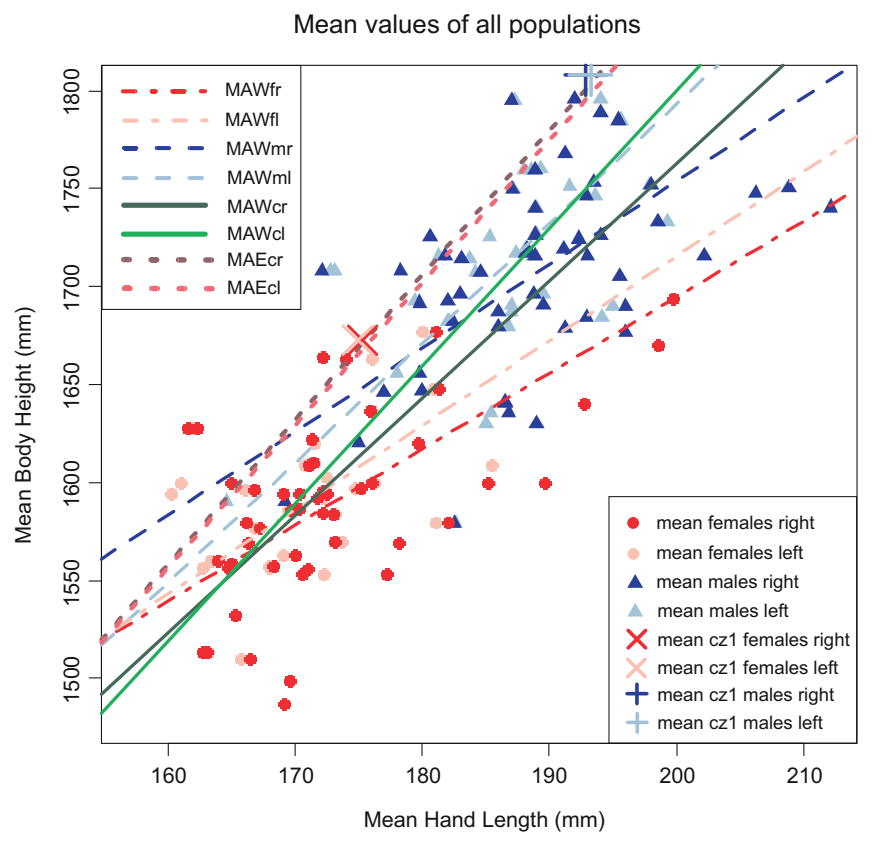

Fig. 3 Mean values the hand length and body height of published population samples and MA (MAW and MAE) regression models developed from them and used for testing. Crosses represent mean values for the Czech sample 1 for a comparison.

\section{RESULTS}

Literature-extracted mean values of the hand length and body height used for construction of the MA models and the literature extracted LS regression equations used for the AR models are show in Fig. 3 and 4, respectively. New regression equations (MAW, MAE, ARW and LSC models) for estimation of stature from the hand length are given in the Table 2. Detailed computational results of all new models are available in the Supplementary materials. In all studied relationships between the hand length and body height correlation coefficients were high and highly statistically significant. This applies also for all regression models.

From Table 2 it is evident that the three groups of models differ systematically in values both of their slopes and intercepts. MA models derived separately for males and females and AR models have relatively low slopes and relatively high intercepts, whereas the MA models for combined sexes have relatively high slopes and low intercepts. The LSC models based on the Czech 1 sample are somewhere in between the MA and AR model.

Crosses in the Fig. 3 and 4 (representing mean values for the Czech sample 1, equal to red and blue dots in the upper left plot in Fig. 5) show that the Czech sample 1 is localized (both for males and females) at the top comparing to the worldwide diversity of published mean values of the human populations for the body height and also for the hand length it is at a relatively high position. Positions of all developed models in relation with the testing samples are presented in the Fig. 5. The majority of individual cases of all five testing samples evi-
Regression models of all populations

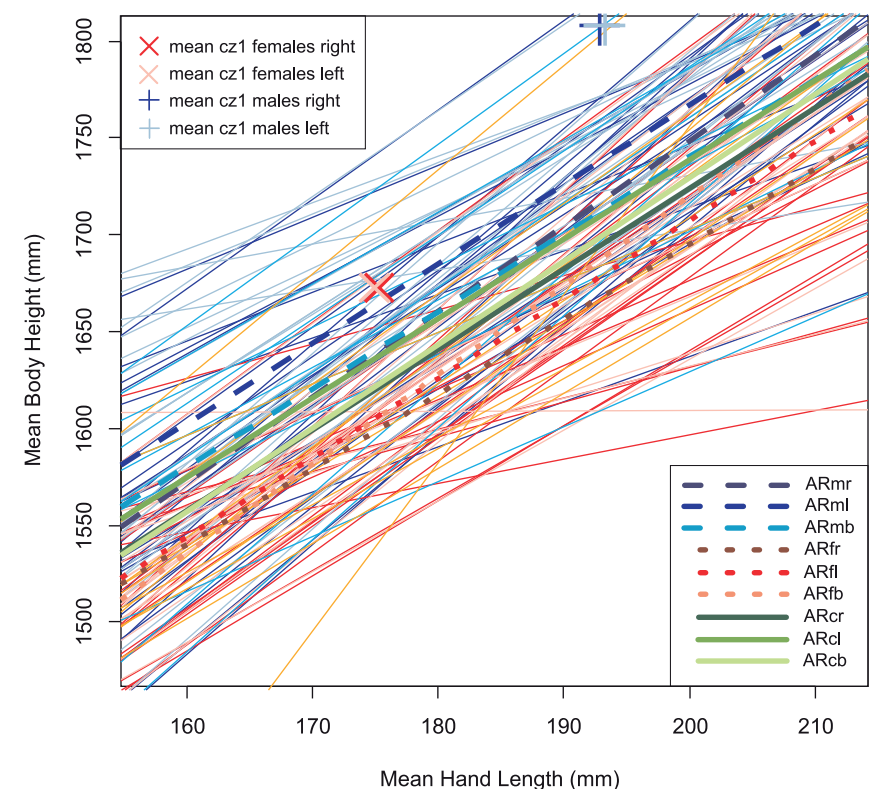

Fig. 4 Regression equations extracted from published literature (thin lines, blue tones - males, red tones - females, others - both, mixed) augmented with ARW models (thick lines) computed from them. Crosses represent mean values for the Czech sample 1 for a comparison. Various tones of blue thin lines represent equations for males, various tones of red thin lines represent females' equations extracted from literature.

\begin{tabular}{|c|c|c|c|c|c|c|c|}
\hline \multicolumn{2}{|c|}{ Model } & \multirow{2}{*}{$\begin{array}{l}\text { sex } \\
\text { males }\end{array}$} & \multirow{2}{*}{$\begin{array}{l}\text { side } \\
\text { right }\end{array}$} & \multirow{2}{*}{$\begin{array}{l}\text { abbreviation } \\
1 \mathrm{MAWmr}\end{array}$} & \multirow{2}{*}{$\begin{array}{c}\mathrm{K} \text { or } \mathbf{N} \\
53\end{array}$} & \multirow{2}{*}{$\begin{array}{l}\text { intercept } \\
902.0333\end{array}$} & \multirow{2}{*}{$\begin{array}{c}\text { slope } \\
4.258204\end{array}$} \\
\hline MA & MAW & & & & & & \\
\hline & (World) & males & left & 2 MAWml & 37 & 571.499 & 6.109978 \\
\hline & & females & right & $3 \mathrm{MAWfr}$ & 49 & 918.2339 & 3.881678 \\
\hline & & females & left & $4 \mathrm{MAWfI}$ & 39 & 853.8375 & 4.308734 \\
\hline & & combined & d right & 5 MAWcr & 102 & 564.9036 & 5.989944 \\
\hline & & combined & d left & $6 \mathrm{MAWcl}$ & 76 & 393.0398 & 7.036905 \\
\hline & MAE & combined & d right & 7 MAEcr & 6 & 375.944 & 7.388543 \\
\hline & (Europe) & combined & d left & $8 \mathrm{MAECl}$ & 6 & 388.1184 & 7.300245 \\
\hline \multirow[t]{9}{*}{ AR } & ARW & males & right & $9 \mathrm{ARmr}$ & 29 & 867.3586 & 4.405117 \\
\hline & (World) & males & left & $10 \mathrm{ARml}$ & 26 & 943.9245 & 4.117142 \\
\hline & & males & both,mixed & $11 \mathrm{ARmb}$ & 11 & 940.614 & 3.998627 \\
\hline & & females & right & $12 \mathrm{ARfr}$ & 25 & 919.4021 & 3.878396 \\
\hline & & females & left & $13 \mathrm{ARfl}$ & 24 & 890.306 & 4.085875 \\
\hline & & females & both,mixed & $14 \mathrm{ARfb}$ & 12 & 798.6924 & 4.603992 \\
\hline & & combined & d right & $15 \mathrm{ARcr}$ & 54 & 891.4528 & 4.161265 \\
\hline & & combined & d left & $16 \mathrm{ARcl}$ & 50 & 918.1876 & 4.102134 \\
\hline & & combined & d both, mixed & 17 ARcb & 23 & 866.5679 & 4.31447 \\
\hline \multirow[t]{6}{*}{ LS } & & males & right & $18 \mathrm{LSCmr}$ & 214 & 782.0298 & 5.321302 \\
\hline & (Czechs) & males & left & $19 \mathrm{LSCml}$ & 214 & 763.521 & 5.405782 \\
\hline & & females & right & $20 \mathrm{LSCfr}$ & 218 & 774.1495 & 5.125686 \\
\hline & & females & left & 21 LSCfI & 218 & 798.8308 & 4.995619 \\
\hline & & combined & d right & $22 \mathrm{LSCcr}$ & 432 & 553.1552 & 6.449626 \\
\hline & & combined & d left & $23 \mathrm{LSCcl}$ & 432 & 572.977 & 6.34143 \\
\hline
\end{tabular}

Table 2 Newly developed regression models subsequently tested on the testing samples. Legend: $K$ - number of included population samples (for $M A$ and AR models), $N$ - number of measured individuals (for LS models). In the abbreviations of models' names: $m$ - males, $f$-females, $c$-combined sexes, $r$ - right hand, $l$ - left hand, $b$ - hands of both sides in a combination in original studies. When computing estimates from the models, hand length should be in millimeters and so are the resulting body height estimates. Also in AR models, published coefficients of regression models were converted from different units to millimeters if necessary (both for the hand length and stature) before computing these AR averages. 
Czech sample 1 with LSC models

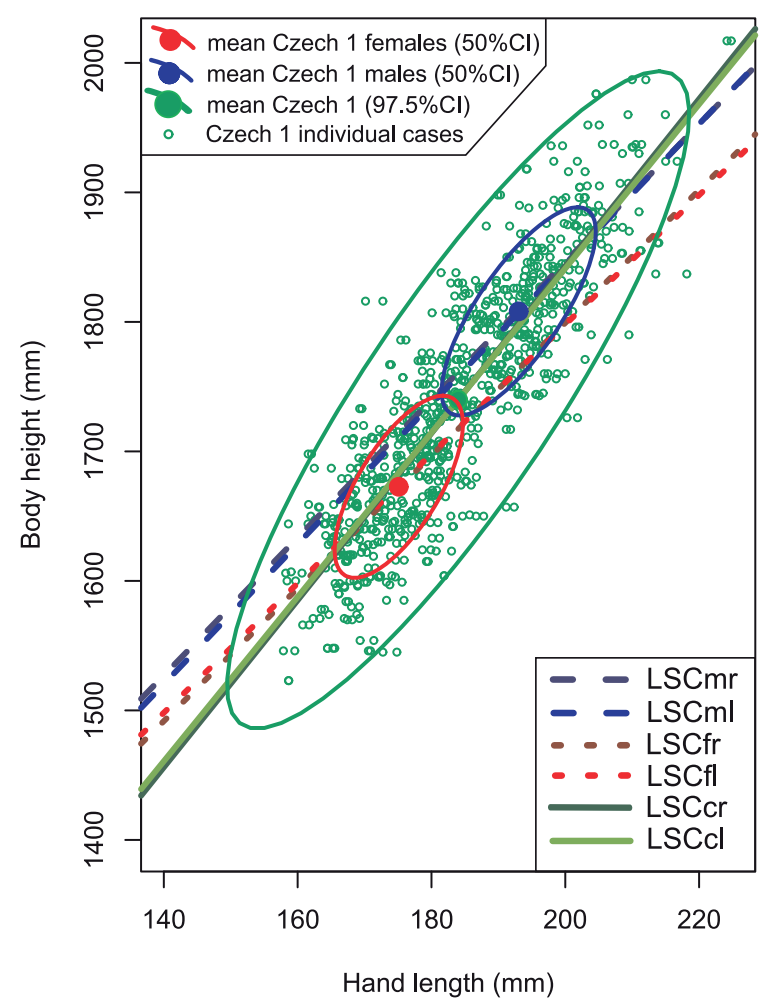

All testing samples with MAW and MAE models

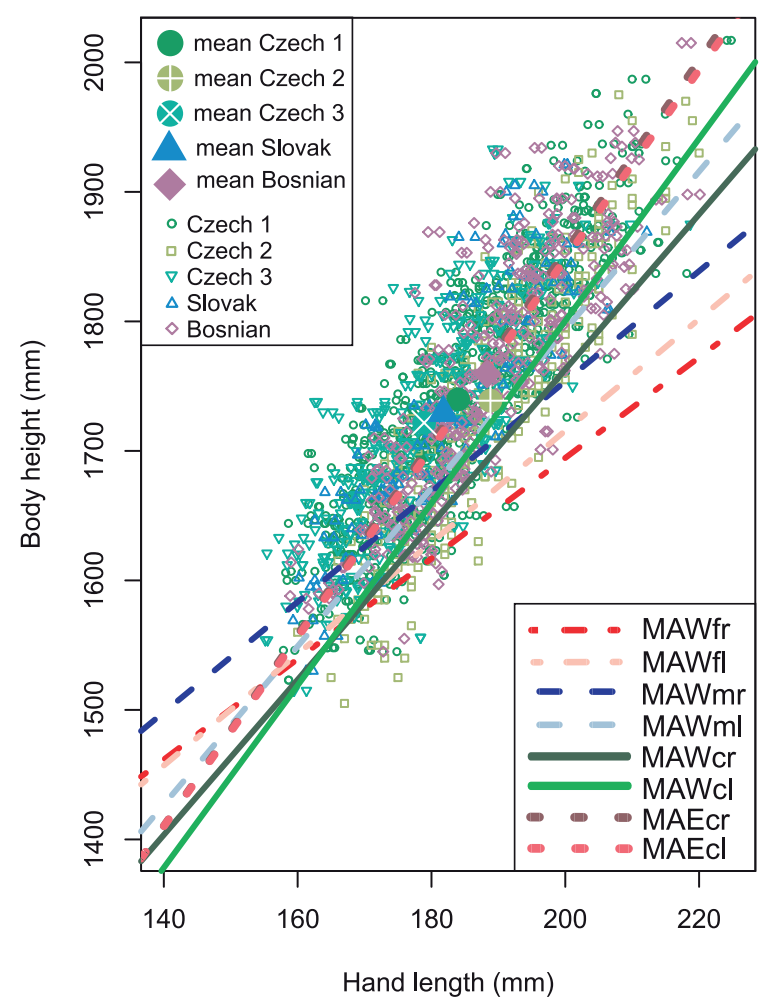

Superimposition of all testing samples

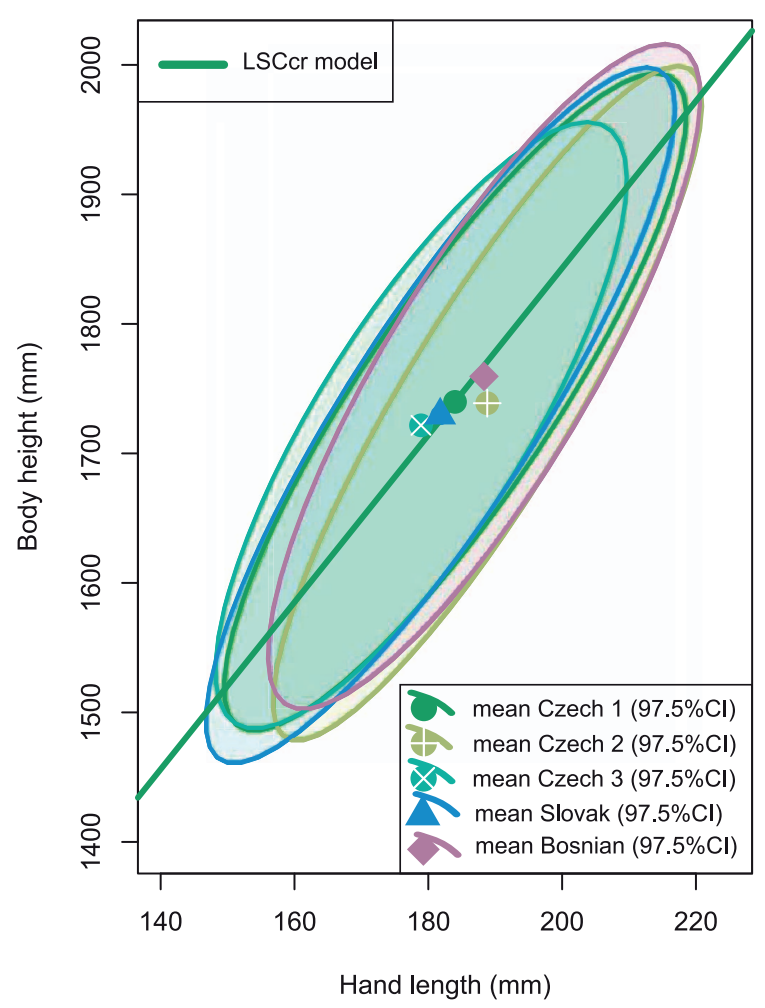

All testing samples with ARW models

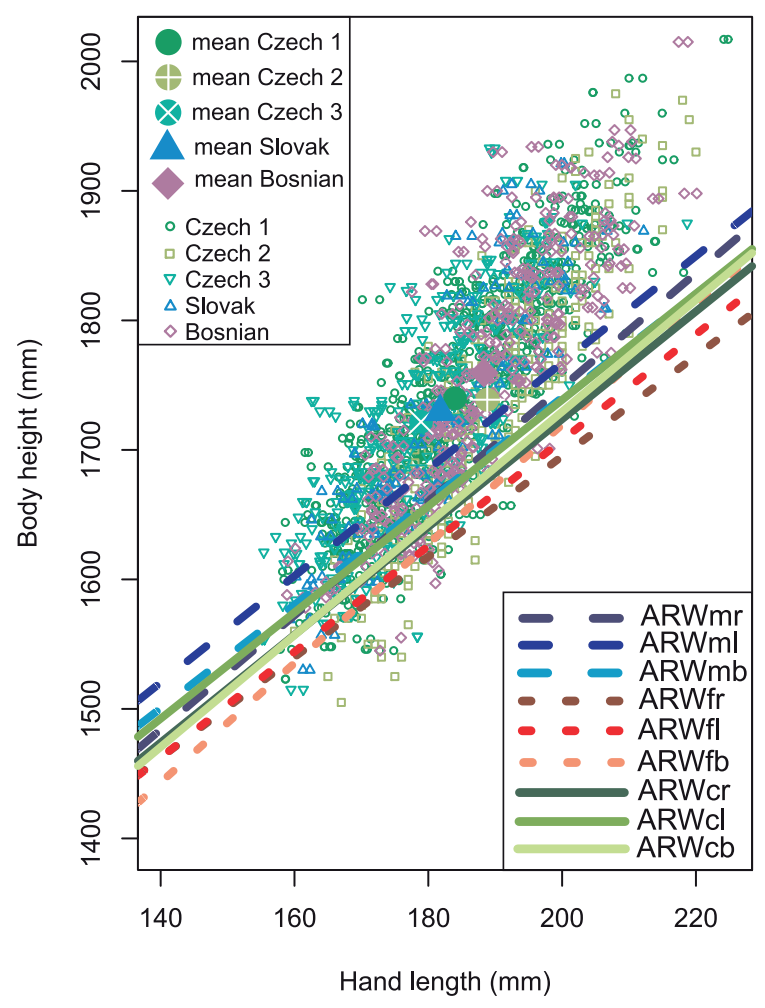

Fig. 5 Testing samples with different views and superimposition with newly developed models (LS, MA and AR). 
dently lie above the course of the tested MA and AR models (except for MAE models). In other words, our testing population samples have substantially higher values both in the hand length and the body height than average whole-World models.

\section{Errors of estimates}

Mean errors of estimates (MEE) and standard deviations of errors of estimates (SDEE) for all combinations of tested equations and testing samples are presented in the Supplementary materials. Fig. 6 shows scatterplots with MEE and SDEE, grouped by different categories that can influence accuracy (i.e. MEE - difference from true body height represented here by the difference from zero error of estimate to both sides) and precision of estimates represented here by the difference of SDEE from the minimum possible standard deviation given by SDEE in LS model applied to the source sample itself; in our case: SDEE of the LSC model (developed from the Czech sample 1) applied to the same data of the Czech sample 1 (horizontal dashed line).

As can be seen from the plots (Fig. 6, Table 3), the errors of estimates were localized mostly in the negative part of the $\mathrm{x}$ axis which means that most of the models underestimated the height of the testing samples comparing to the true body height, though very differently for different models. The largest differences, however, were found among the estimates derived from different methods. As expected, the LSC models yielded the best outputs. Their MEEs were localized almost symmetrically around zero and reached relatively lowest SDEEs. At the same time, different testing samples did not differ very much in overall accuracy (MEE) but some differences can be seen in the precision (SDEE) of estimates. This means that belonging to one or the other testing sample did not crucially affect the systematic shift from true height but can affect the dispersion of estimates. While in all three Czech testing samples all methods were relatively close to each other (though in a different position in the SDEE axis), the estimates of Bosnian and Slovak testing samples by different methods were relatively more disperse in the range of the SDEE values. The estimates of females were substantially better (generally lower MEE and SDEE) than those of males and the estimates for samples of combined sexes were somewhere in between in MEE but have higher SDEEs. The body side of the measured hand (both the source samples and testing samples) evidently did not affect the estimates except the estimates in nonstandard combinations of hands (both hands) in the source sample - these estimates underestimated the body height more than estimates from models made strictly on right or left hands. MAW models seriously underestimated body height. The errors of MAW models reached the highest diversity of mean values that ranged from +55.3 to $-148.7 \mathrm{~mm}$, as well as the highest diversity in SDEEs that reached the maximum at almost $61.7 \mathrm{~mm}$ (same with the ARW models). On the contrary, MAE models - the equations constructed on the selection of six European samples only - yielded results close to those of

\begin{tabular}{lcccccc}
\hline & \multicolumn{3}{c}{ MEE $(\mathbf{m m})$} & \multicolumn{3}{c}{ SDEE $(\mathbf{m m})$} \\
& median & $\min$ & $\max$ & median & $\min$ & $\max$ \\
\hline MAW & -64.8 & -148.7 & 55.3 & 48.7 & 35.4 & 61.7 \\
MAE & -7.8 & -34.1 & 38.9 & 47.9 & 37.7 & 59.5 \\
ARW & -74.4 & -148.2 & 17.3 & 51.0 & 36.2 & 61.7 \\
LSC & 0.0 & -54.1 & 72.5 & 48.6 & 35.4 & 56.7 \\
\hline
\end{tabular}

Table 3 Basic descriptive statistics of MEEs and SDEEs grouped by estimation methods.

\begin{tabular}{|c|c|c|c|c|c|c|}
\hline & \multicolumn{6}{|c|}{ LSC models } \\
\hline & \multicolumn{3}{|c|}{ MEE (mm) } & \multicolumn{3}{|c|}{ SDEE (mm) } \\
\hline & median & $\min$ & $\max$ & median & $\min$ & $\max$ \\
\hline Czech sample 1 & 0.0 & -46.0 & 42.2 & 44.5 & 42.9 & 49.5 \\
\hline Czech sample 2 & 29.9 & -24.0 & 72.5 & 43.1 & 41.9 & 50.9 \\
\hline Czech sample 3 & -11.5 & -52.5 & 29.9 & 50.2 & 45.4 & 53.3 \\
\hline Slovak sample & -3.7 & -54.1 & 43.7 & 49.4 & 35.4 & 53.9 \\
\hline \multirow[t]{4}{*}{ Bosnian sample } & 5.6 & -47.9 & 54.6 & 53.4 & 38.4 & 56.7 \\
\hline & \multicolumn{6}{|c|}{ MAE models } \\
\hline & \multicolumn{3}{|c|}{ MEE (mm) } & \multicolumn{3}{|c|}{ SDEE (mm) } \\
\hline & median & $\min$ & $\max$ & median & $\min$ & $\max$ \\
\hline Czech sample 1 & -6.2 & -12.3 & -1.5 & 47.6 & 46.4 & 48.3 \\
\hline Czech sample 2 & 30.0 & 20.3 & 38.9 & 43.4 & 43.0 & 43.8 \\
\hline Czech sample 3 & -24.8 & -34.1 & -20.6 & 52.2 & 47.9 & 56.3 \\
\hline Slovak sample & -11.8 & -22.1 & -5.0 & 47.0 & 37.7 & 56.4 \\
\hline Bosnian sample & 5.6 & -6.1 & 19.9 & 52.0 & 41.0 & 59.5 \\
\hline
\end{tabular}

Table 4 Basic descriptive statistics of MEEs and SDEEs for LSC and MAE models grouped by testing samples.

LSC models. The majority of ARW models underestimated body height, their SDEEs were comparable with those of MAE models but their MEEs ranged from +17.3 to $-148.2 \mathrm{~mm}$, so the ARW models were as unsuitable for our testing samples as the MAW models.

To take a closer look at the results, we focused on the two methods that gave the best results (LSC, MAE) and additionally divided the plots according to the congruence or incongruence of sex and body side between source and testing samples (source - the sample from which the model was computed). From the results (Fig. 7, Table 4) it is evident that MAE models provided similar result as LSC models and in both methods the median MEE represented at most several centimeters (Table 4). Moreover, the dispersion of MEE in different MAE models is even closer than for LSC models. At this level, the highest differences spread from different testing samples when MEE values of the Czech sample 1 (from definition), Slovak sample and Bosnian sample spread approximately along zero vertical line (Fig. 7), while Czech sample 2 mostly overestimated the body height and Czech sample 3 mostly underestimated the body height. Congruence in body side between the source and testing sample has no effect on the estimates. However, congruence in sex was very important since it decreased both the range of MEEs and SDEEs.

\section{DISCUSSION}

In this study, equations for stature estimation were developed (side and sex-specific equations) from the hand length using three different types of regression methods: Least Squares 


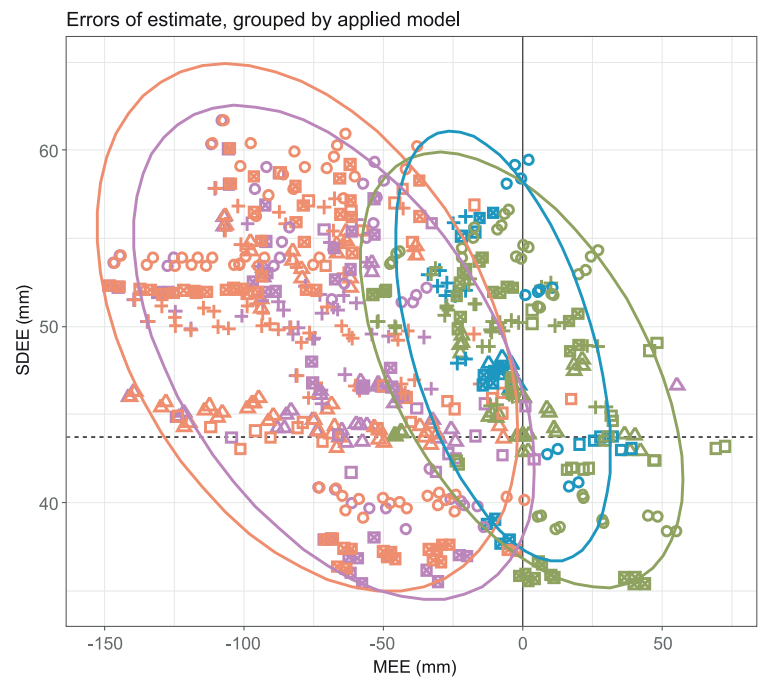

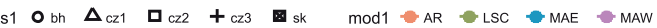

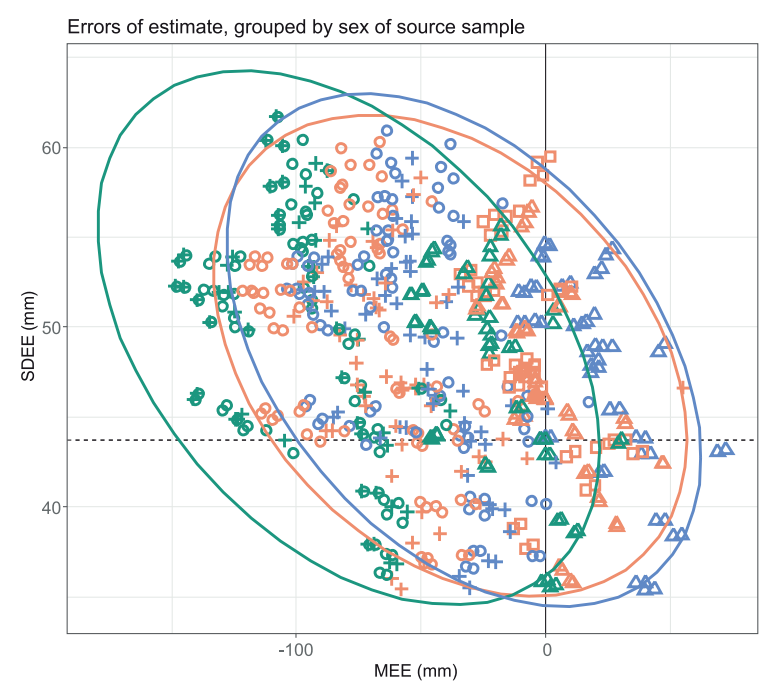

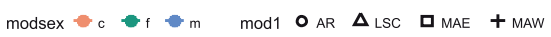

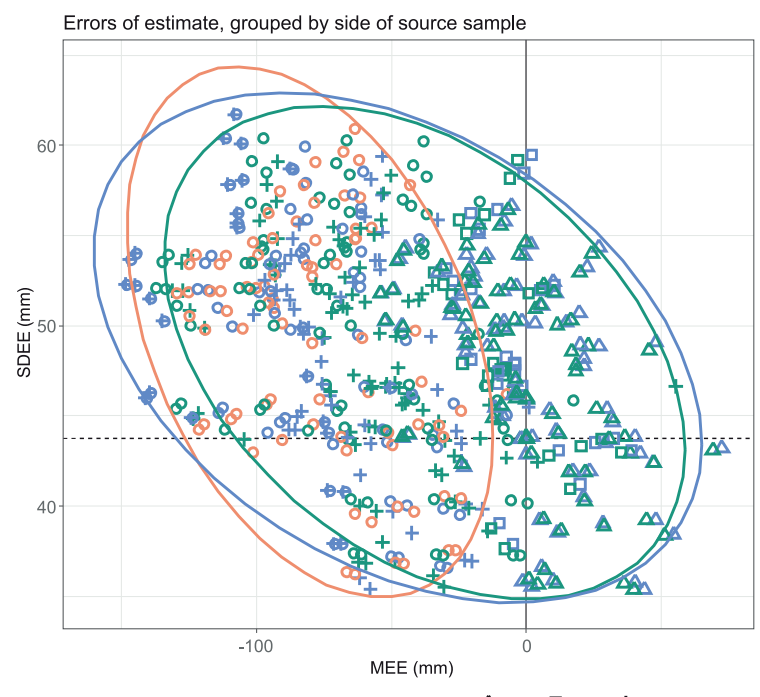

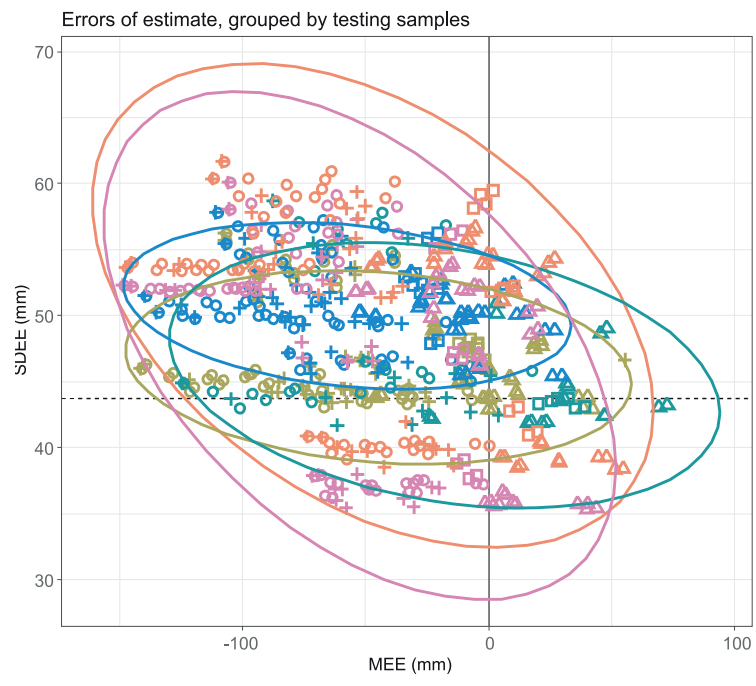

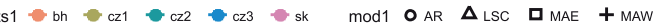
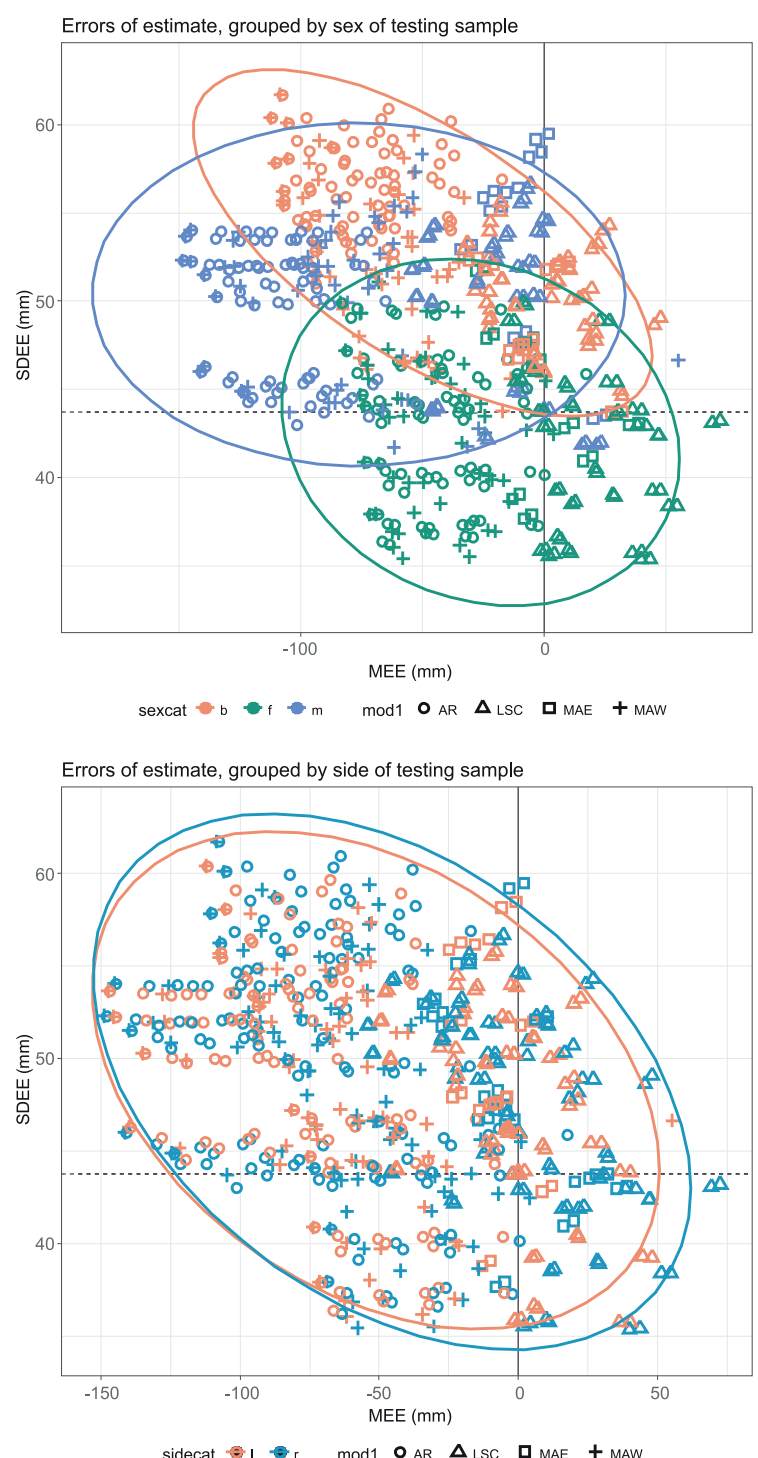

Fig. 6 Comparison of estimation errors (Mean Error of Estimate vs. Standard Deviation of Errors of Estimates) of all tested models grouped by different categories. Dashed horizontal line represents SDEE for LSC model derived from right hands of males of the Czech sample 1 applied to the same sample ( $\mathrm{SDEE}=43.7 \mathrm{~mm}, \mathrm{MEE}=0.00 \mathrm{~mm}$ ). Ellipses represent $95 \%$ confidence zone. 
Errors of estimate (LSC, MAE), grouped by applied model

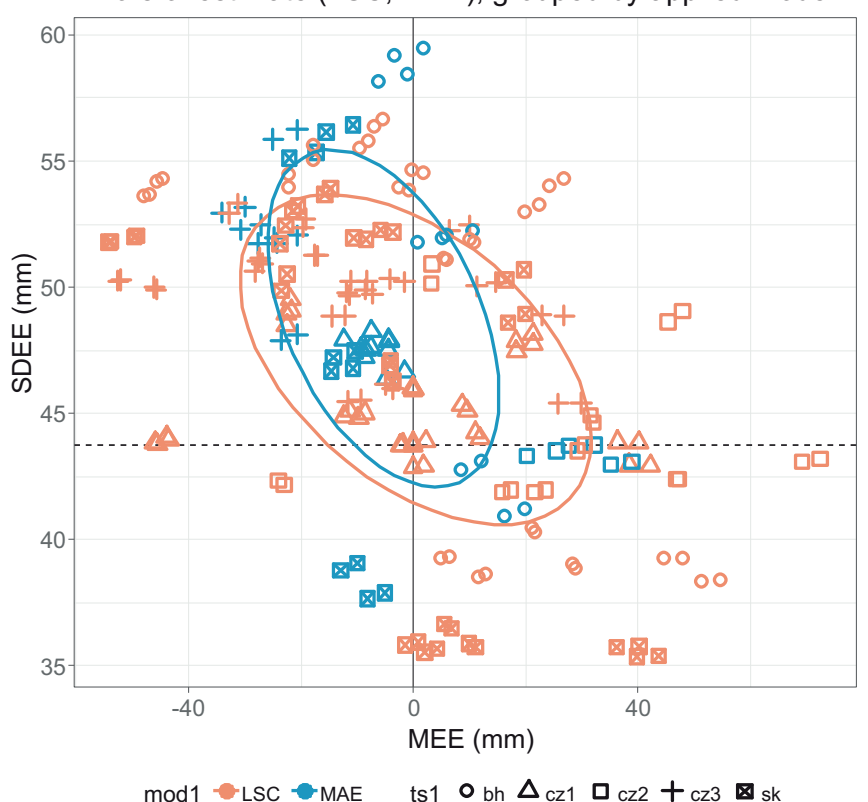

Errors of estimate (LSC, MAE), grouped by sex congruence

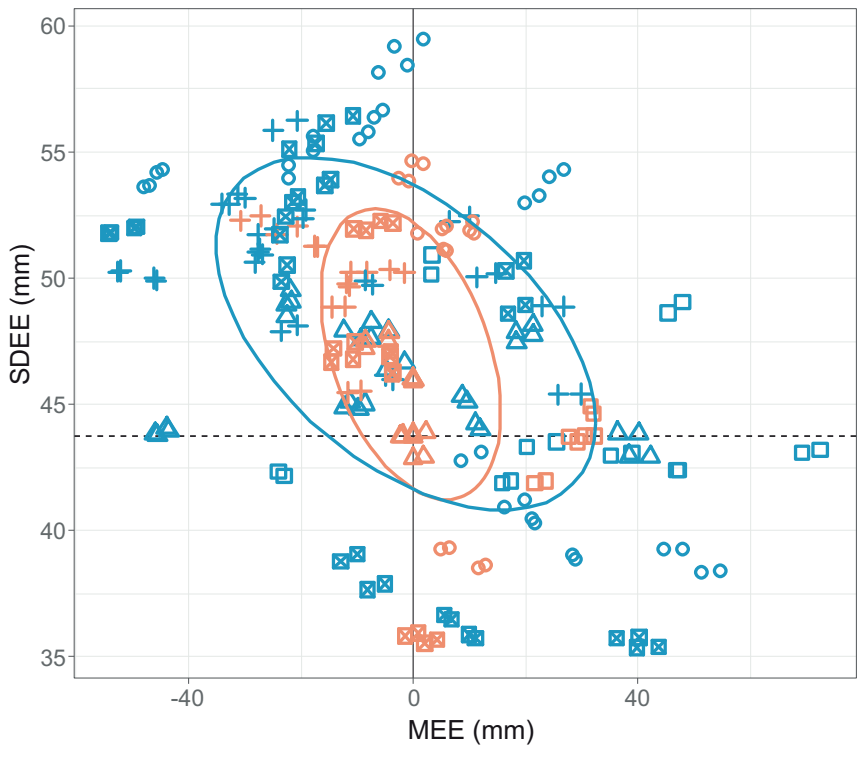

congr.sex - congruent - incongruent ts1 $\mathbf{O}_{\mathrm{bh}} \boldsymbol{\Delta}_{\mathrm{cz} 1} \mathbf{\square}_{\mathrm{cz} 2}+\mathrm{cz3} \quad \boldsymbol{\otimes}_{\mathrm{sk}}$
Errors of estimate (LSC, MAE), grouped by testing sample

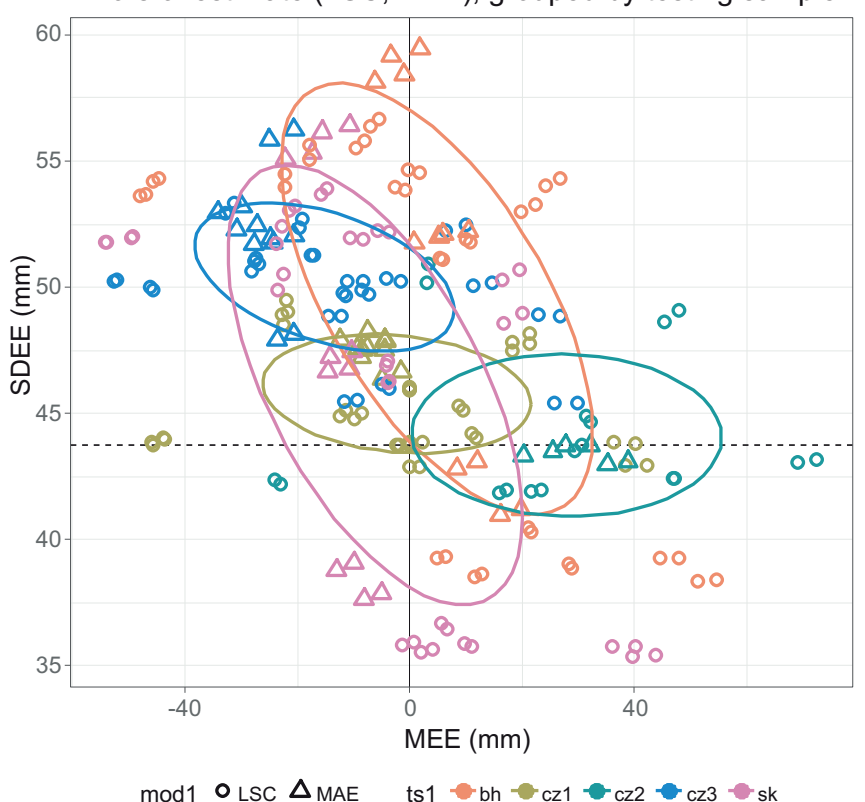

Errors of estimate (LSC, MAE), grouped by side congruence

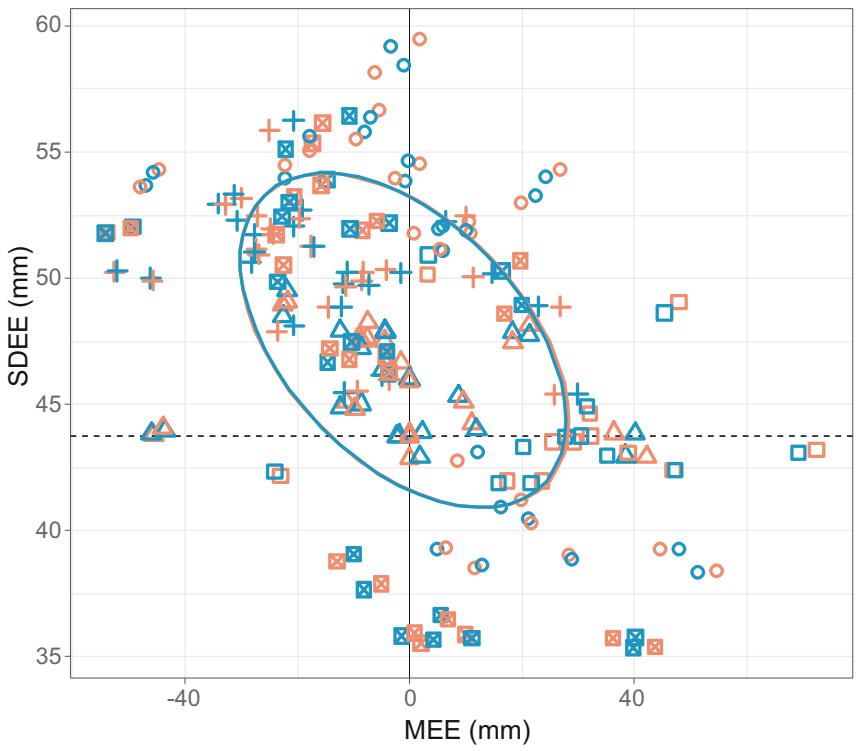

congr.side - congruent -incongruent ts1 $\bigcirc_{\text {bh }} \triangle_{\mathrm{cz} 1} \quad \square_{\mathrm{cz} 2}+\mathrm{cz3} \quad \nabla_{\mathrm{sk}}$

Fig. 7 Comparison of estimation errors (Mean Error of Estimate vs. Standard Deviation of Errors of Estimates) of the LSC and MAE models grouped by different categories. Dashed horizontal line represents SDEE for LSC model derived from right hands of males of the Czech sample 1 applied to the same sample $(\mathrm{SDEE}=43.7 \mathrm{~mm})$. Ellipses represent $50 \%$ confidence zone.

Models, Average Regression Models and Reduced Major Axis Models. LS models were developed based on our primary data and only for the sample of Czech origin (Europe) whereas AR models were developed only from the whole World data. Only MA models were developed for European origin populations as well as for world-wide populations.

The results indicate that our newly developed "worldwide" equations (neither those created using Reduced Major Axis interposition through the world populations average values nor those created using averaged values of regression coefficients) do not permit making practically usable body height estimations based on hand length in any of our five testing samples. We must therefore discuss the result in comparison to Sjøvold's (1990) method on long bones (the analogies of which are our MA models). When comparing the population sources for Sjøvold's and our models, the difference in samples from various parts of the world is clearly apparent. While in the source data of Sjøvold's organic correlation model, out 
of 44 samples 32 were of European origins (about 26 samples from Europe and additional 6 samples from US of European origin), our "W" ("worldwide") models only contains 6 samples of European origin ( 3 male and 3 female samples) and the rest is non-European, mainly Asian (See Appendix 1 and 2). Both the European samples we collected in literature (6 samples) and the samples we collected empirically (10 samples) can be all found at the very upper boundary of the worldwide population cluster (Fig. 3). On one hand, our MAW models represent/cover the "whole world" much better than Sjøvold's 44 population sample selection. His data, from the perspective of origin range, are limited and therefore the organization/location of his central tendency values is significantly narrower. Given the degree of diversity among the source populations, Sjøvold's model is therefore, by nature, closer to our MAE model than to our MAW model). (Moreover, in Sjøvold's data there are not only more samples of European origin than non-European samples, but also more male than female samples, therefore his equations for stature estimation using bone lengths will be more suitable for males and for individuals of European origin. On the contrary, our equations will be probably more suitable for samples of Asian origin. In the future, it would be possible and suitable to create Reduced Major Axis Models from separated large groups of Asian populations similarly to our MAE models. On the other hand, an equation based on our "world-wide" selection is a source of lower accuracy for populations located farther from the population cloud axis and body height estimates generated with such equation are practically useless as estimation error can reach up to tens of centimeters and also estimation inaccuracy is rising.

It needs to be made clear that our MAE model (which was only based on 6 mean values) is only based on Slavic origin populations and the same is true for our testing samples. Therefore, a question remains - what would be the stature estimate outcomes provided by the MAE model, if these were tested on original data of European, but not Slavic origin (these data, however, were not available to us).

Despite the similarity of all five testing samples (and their sex and laterality sub-groups), differences come to light under a closer look. These differences can result from (a) true differences in body size and thus different position of population means towards a common tested regression equation and (b) real differences in hand to height proportions (and their size dependence - allometry) among the five testing samples, i. e. population differences (Czechs vs. Slovaks vs. Bosnians) and generation (Czechs 1 and Czechs 3 vs. Czechs 2). The similarity (narrow dispersion of SDEEs) of all three Czech testing samples (regardless of measuring methods) comparing to Bosnian and Slovak samples (with wide dispersion of SDEEs) might be an evidence for some true biological differences. It is possible, however, that also (c) different modes of measuring hand length can have an effect. It is worthy of notice that the Slovak and Bosnian samples are nearer in the estimation results to the Czech sample 1 (i.e. the samples where data was collected using a desktop scanner and measured on 2D hand images) while the two remaining Czech samples are localized further from the zero line in the plot, and in addition, both in different direction. It is possible that there were mild differences between the three modes of measurement and this should be experimentally tested by comparing all the three methods in one sample. However, simultaneous influence of both mechanisms (true average differences and measurement differences) on recorded differences of estimations between testing samples can't be ruled out.

\section{CONCLUSION}

It is evident form the performed testing that cross-population based models are not suitable for body height estimation from hand length as the systematic shift compared to the particular population can be so significant that the resulting estimates might be practically pointless. In case that the cross-population model is limited to a narrower geographically confined population group (in our case European), the universal model estimates can near in their accuracy and preciseness the estimates based on a population-specific model calculated using the Least Squares method. As an output, we can recommend, if possible, (a) using population specific LS model (chosen from our list in Appendix 2 or other literature sources) or (2) developing ad hoc a new Reduced Major Axis model from population means (our Appendix 1) for a narrower geographically limited set of populations.

Although an application of stature estimation from separated hand might not be very frequent, the principles tested in the study apply for any stature estimations from various partial body length measurements. Therefore, we propose considering similar consequences also when estimating the body height from a bone length in forensic skeletal cases.

\section{ACKNOWLEDGEMENTS}

We would like to thank all of our volunteers for their participation. This study was carried out with financial support provided by Project Grant at Masaryk University, projects no. MUNI/A/1219/2016 and MUNI/A/1279/2016.

Preliminary version of this study was presented in the form of a poster titled „Stature estimation from the hand length: an attempt to population non-specific method" in The 21st Triennial Meeting of the International Association of Forensic Sciences 2017, Toronto, Canada, 2017.

\section{REFERENCES}

Agnihotri, A. K - Agnihotri, S. - Jeebun, N. - Googoolye, K. (2008): Prediction of stature using hand dimensions. Journal of Forensic and Legal Medicine, 15(8), 479-482.

Ahmed, A. A. (2013): Estimation of stature from the upper limb measurements of Sudanese adults. Forensic Science International, 228(1-3), 178. e1-178.e7. 
Ahmed, A. A - Taha, S. (2016): Cephalo-facial analysis to estimate stature in a Sudanese population. Legal Medicine, 20, 80-86.

Akhlaghi, M. - Hajibeygi, M. - Zamani, N. - Moradi, B. (2012): Estimation of stature from upper limb anthropometry in Iranian population. Journal of Forensic and Legal Medicine, 19(5), 280-284.

Bedić, Ž. - Novak, M. - Šlaus, M. (2013): Anthropological analysis of the human skeletal remains from the late antique necropolis (4th century AD) of Tekić-Treštanovačka gradina near Požega. Arheološki radovi i rasprave, 17, 301-320.

Bouchalová, M. (1987): Vývoj během dětství: Brněnská růstová studie. Praha: Avicenum.

Brits, D. M. - Bidmos, M. A. - Manger, P. R. (2017): Stature estimation from the femur and tibia in Black South African sub-adults. Forensic Science International, 270, 277.e1-277.e10.

Chikhalkar, B. G. - Mangaonkar, A. A. - Nanandkar, S. D. - Peddawad, R. G. (2010): Estimation of Stature from Measurements of Long Bones, Hand and Foot Dimensions. Journal of Indian Academy of Forensic Medicine, 32(4), 329-331.

Cummins, H. - Waits, W. J. - McQuitty, J. T. (1941): The Breadths of Epidermal Ridges on the Finger Tips and Palms: A Study of Variation. The American Journal of Anatomy, 68(1), 127-150.

Dayal, M. R. - Steyn, M. - Kuykendall, K. L. (2008): Stature estimation from bones of South African whites. South African Journal of Science, 104(34), 124-128.

Duyar, İ. - Pelin, C. (2010): Estimating body height from ulna length: need of a population-specific formula. Eurasian Journal of Anthropology 1(1), $11-17$.

Goswami, R. B. - Thakur, P. S. - Dadu, S. K. - Rastogi, A. K. (2016): Estimation of stature from anthropometry of hand: an interesting autopsy based study in Madhya Pradesh, India. International Journal of Research in Medical Sciences, 4(6), 1873-1878.

Grasgruber, P. - Popović, S. - Bokuvka, D. - Davidović, I. - Hřebíćková, S. Ingrová, P. - Potpara, P. - Prce, S. - Stračárová, N. (2017): The mountains of giants: an anthropometric survey of male youths in Bosnia and Herzegovina. Royal Society Open Science, 4(4), 161054.

Habib, S. R. - Kamal, N. N. (2010): Stature estimation from hand and phalanges lengths of Egyptians. Journal of Forensic and Legal Medicine, 17(3), $156-160$.

Hammer, Ø. - Harper, D. A. T. - Ryan, P. D. (2001): Paleontological Statistics Software Package for Education and Data Analysis. Palaeontologia Electronica $4(1)$.

Howley, D. - Howley, P. - Oxenham, M. F. (2018): Estimation of sex and stature using anthropometry of the upper extremity in an Australian population. Forensic Science International, 287, 220.e1-220.e10.

Ibegbu, A. O. - Danjuma, Z. C. - Hamman, W. O. - Umana, U. E. - Ikyembe, D. - Musa, S. A. (2012): Association of the index (2nd) and ring (4th) digit ratios with some physical attributes in Ebira Ethnic Group of Nigeria. ATI - Applied Technologies \& Innovations, 7(2), 46-54.

Ingrová, P. - Králík, M. - Bártová, V. (2017): Relationships between the Hand Grip Strength and Body Composition. Slovenská antropológia, 20(1), $30-43$.

Ishak, N-I. - Hemy, N. - Franklin, D. (2012): Estimation of stature from hand and handprint dimensions in a Western Australian population. Forensic Science International, 216(1-3), 199.e1-199.e7.

Jasuja, O. P. - Singh, G. (2004): Estimation of stature from hand and phalange length. Journal of Indian Academy of Forensic Medicine, 26(3), 100-106.

Jee, S. - Yun, M. H. (2015): Estimation of stature from diversified hand anthropometric dimensions from Korean population. Journal of Forensic and Legal Medicine, 35, 9-14.

Jee, S. - Yun, M. H. (2016): An anthropometric survey of Korean hand and hand shape types. International Journal of Industrial Ergonomics, 53, 10-18.

Kamp, K. A. - Timmerman, N. - Lind, G. - Graybill, J. - Natowsky, I. (1999): Discovering childhood: using fingerprints to find children in the archaeological record. American Antiquity, 64(2), 309-315.

Krishan, K. - Kanchan, T. - Asha, N. (2012): Estimation of stature from index and ring finger length in a North Indian adolescent population. Journal of Forensic and Legal Medicine, 19, 285-290.

Krishan, K. - Kanchan, T. - DiMaggio, J. A. (2010): A study of limb asymmetry and its effect on estimation of stature in forensic case work. Forensic Science International, 200(1-3), 181.e1-181.e5.
Krishan, K. - Kanchan, T. - Kharoshah, M. A. (2015): Estimation of stature from handprint dimensions - Positional variations in real crime scene situations. Egyptian Journal of Forensic Sciences, 5, 129-131.

Krishan, K. - Sharma, A. (2007): Estimation of stature from dimensions of hands and feet in a North Indian population. Journal of Forensic and Legal Medicine, 14(6), 327-332.

Kyllonen, K. M. - Simmons-Ehrhardt, T. - Monson, K. L. (2017): Stature estimation using measurements of the cranium for populations in the United States. Forensic Science International, 281, 184.e1-184.e9.

Legendre, P. (2014): lmodel2: Model II Regression. Available from: https:// CRAN.R-project.org/package $=$ lmodel 2

Mahakizadeh, S. - Moghani-Ghoroghi, F. - Moshkdanian, G. - Mokhtari, T. - Hassanzadeh, G. (2016): The determination of correlation between stature and upper limb and hand measurements in Iranian adults. Forensic Science International, 260, 27-30.

Mahakkanukrauh, P. - Khanpetch, P. - Prasitwattanseree, S. - Vichairat, K. Case, D. T. (2011): Stature estimation from long bone lengths in a Thai population. Forensic Science International, 210, 279.e1-279.e7.

Malina, R. M. (1994): Physical activity and training: effects on stature and the adolescent growth spurt. Medicine \& Science in Sports \& Exercise, 26(6), 759-766.

Moorthy, T. N - Yin, T. Y. (2016): Regression analysis to determine stature from fingerprints in Malaysian Chinese for person identification. Journal of Bio Innovation, 5(3), 411-418.

Mundorff, A. Z - Bartelink, E. J - Murad, T. A. (2014): Sexual dimorphism in finger ridge breadth measurements: a tool for sex estimation from fingerprints. Journal of forensic sciences, 59(4), 891-897.

Nor, F. M. - Abdullah. N. - Mustapa, A-M. - Wen, L. Q. - Faisal, N. A. Asyikin, D. A. - Nazari, A. (2013): Estimation of stature by using lower limb dimensions in the Malaysian population. Journal of Forensic and Legal Medicine, 20(8), 947-952.

Özaslan, A. - İşcan, M. Y. - Özaslan, I. - Tuğcu, H. - Koç, S. (2003): Estimation of stature from body parts. Forensic Science International, 132, 40-45.

Özaslan, A. - Karadayi, B. - Kolusayin, M. O. - Kaya, A. - Afsin, H. (2012): Predictive role of hand and foot dimensions in stature estimation. Romanian Journal of Legal Medicine, 20(1), 41-46.

Özaslan, A. - Koç, S. - Özaslan, I. - Tuğcu, H. (2006): Estimation of stature from upper extremity. Military Medicine, 171(4), 288-291.

Pal, A. - De, S. - Sengupta, P. - Maity, P. - Dhara, P. C. (2016): Estimation of stature from hand dimensions in Bengalee population, West Bengal, India. Egyptian Journal of Forensic Sciences, 6(2), 90-98.

Paulis, M. G. (2015): Estimation of stature from handprint dimensions in Egyptian population. Journal of Forensic and Legal Medicine, 34, 55-61.

Polcerová, L. - Králík, M. (2016): Estimation of Human Stature Using Program Stature. Pravěk, 24, 295-308.

Prokopec, M. (1967): Somatometrie. In: Antropologie. Praha: Academia, 26-73.

Rahman, Q. - Korhonen, M. - Aslam, A. (2005): Sexually dimorphic 2D:4D ratio, height, weight, and their relation to number of sexual partners. Personality and Individual Differences, 39(1), 83-92.

Ranson, R. - Stratton, G. - Taylor, S. R. (2015): Digit ratio (2D:4D) and physical fitness (Eurofit test battery) in school children. Early Human Development, 91(5), 327-331.

Rastogi, P. - Nagesh, K. R. - Yoganarasimha, K. (2008): Estimation of stature from hand dimensions of north and south Indians. Legal Medicine, 10(4), 185-189.

Raxter, M. H. - Ruff, C. B. - Azab, A. - Erfan, M. - Soliman, M. - El-Sawaf, A. (2008): Stature Estimation in Ancient Egyptians: A NewTechnique Based on Anatomical Reconstructionof Stature. American Journal of Physical Anthropology, 136(2), 147-155.

Rexhepi, A. M. - Brestovci, B. (2015): Prediction of Stature According to Three Head Measurements. International Journal of Morphology, 33(3), 1151-1155.

Reynolds, M. S. - MacGregor, D. M. - Alston-Knox, C. L. - Meredith, M. Barry, M. D. - Schmutz, B. - Gregory, L. S. (2018): Bayesian modeling predicts age and sex are not required for accurate stature estimation from femoral length. Forensic Science International [Internet], 289, 452. e1-452.e14.

Rohlf, F. J. (2013): tpsDig, digitize landmarks and outlines, version 2.17 Department of Ecology and Evolution, State University of New York at Stony Brook. 
Rösing, F. W. (1988): Körperhöhenrekonstruktion aus Skelettmassen. In: Knussmann R, editor. Antropologie, Handbuch der verleichenden Biologie der Menschen. Band I. Wesen und Methoden der Antropologie. Stuttgart - New York: Gustav Fischer Verlag. p 586-600.

Sen, J. - Kanchan, T. - Ghosh, A. - Mondal, N. - Krishan, K. (2014): Estimation of stature from lengths of index and ring fingers in a North-eastern Indian population. Journal of Forensic and Legal Medicine, 22, 10-15.

Sjøvold, T. (1990): Estimation of stature from long bones utilizing the line of organic correlation. Human evolution, 5(5), 431-447.

Torimitsu, S. - Makino, Y. - Saitoh, H. - Sakuma, A. - Ishii, N. - Yajima, D. Inokuchi, G. - Motomura, A. - Chiba, F. - Yamaguchi, R. - Hashimoto, M. - Hoshioka, Y. - Iwase, H. (2017): Stature estimation in a contemporary Japanese population based on clavicular measurements using multidetector computed tomography. Forensic Science International, 275, 316. e1-316.e6.

\section{AUTHORS}

Ingrová, Pavlína (1987, Brno), is a PhD student of anthropology at Masaryk University. Her research focuses on human sociosexuality and morphology of hand (both in relation to human body/physical features).

Králík, Miroslav (1973, Brno), is a biological anthropologist. His research focuses on human sexual dimorphism in physical features and behavior, human ontogenetic adaptations and developmental stress factors.

Věra Bártová (1987, Brno), is a PhD student of anthropology at Masaryk University. She also has bachelor degree from Theology from Palacký University Olomouc. Her research focuses on anthropology, religion and sexuality. She is a member of the Czech Anthropological Society.
Uhrová, P. - Beňuš, R. - Masnicová, S. - Obertová, Z. - Kramárová, D. - Kyselicová, K. - Dörnhöferová, M. - Bodoriková, S. - Neščáková, E. (2015) Estimation of stature using hand and foot dimensions in Slovak adults. Legal Medicine, 17(2), 92-97.

Zeman, T. - Králík, M. (2012a): Historický přehled principů tvorby metod pro odhad výšky postavy člověka na základě skeletu. Anthropologia Integra, 3(1), 7-22.

Zeman, T. - Králík, M. (2012b): Assumptions for using line of organic correlation for stature estimation. Slovenská antropológia, 15(2), 63-70.

Zulkifly, N-R. - Wahab, R. A. - Layang, E. - Ismail, D. - Desa, W. N. S. M. Hisham, S. - Mahat, N. A. (2018): Estimation of stature from hand and handprint measurements in Iban population in Sarawak, Malaysia and its applications in forensic investigation. Journal of Forensic and Legal Medicine, 53, 35-45.

Čuta, Martin (1979, Brno), works as an assistant professor at the Department of Anthropology, Faculty of Science, Masaryk University (Brno). He focuses his research on physical anthropology - growth and development, functional anthropology, sports anthropology and anthropometry. His teaching activities include courses of anatomy for anthropologists, ergonomics, applied and sports anthropology as well as methodological and introductory courses in anthropology.

Pavel Grasgruber (1974), graduated from classical archeology at Charles University in Prague. He is currently working at the Faculty of Sports Studies, Masaryk University in Brno, where he is involved in research in the field of dietetics, anthropology (project in the Dinar Alps) and lifestyle of Czech youth.

Bokůvka, Dominik (1991, Prostějov), is a PhD student of kinanthropology at Masaryk University, Brno. His main field of study is a human being in relation to physical activity. Dominik is regularly publishing scientific papers in peer reviewed journals and proceedings. 


\section{Stature Estimation from the Hand Length: Testing Cross-Population Methods}

\section{Appendix 1}

Tab. 1. Complete table of applied population samples - hand and height measurements.

\begin{tabular}{|c|c|c|c|c|c|c|c|c|c|c|}
\hline \multirow[b]{2}{*}{ Study } & \multirow[b]{2}{*}{ state } & \multirow{2}{*}{$\begin{array}{c}\text { measuring } \\
\text { instruments } \\
(\mathrm{H} / \mathrm{HL})\end{array}$} & \multirow[b]{2}{*}{ age } & \multirow[b]{2}{*}{ sex } & \multirow[b]{2}{*}{$\mathbf{N}$} & \multicolumn{2}{|c|}{ height } & \multicolumn{3}{|c|}{ hand lenght } \\
\hline & & & & & & mean & sd & mean & sd & side \\
\hline \multirow{4}{*}{ Geetha et al.(2015) } & \multirow{4}{*}{ India } & \multirow{4}{*}{$\mathrm{A} / \mathrm{a}$} & \multirow{4}{*}{$20-30$} & \multirow{2}{*}{$\mathrm{m}$} & \multirow{2}{*}{100} & \multirow{2}{*}{1579.5} & \multirow{2}{*}{64.2} & 182.5 & 10.9 & $\mathrm{R}$ \\
\hline & & & & & & & & 182.6 & 11.0 & $\mathrm{~L}$ \\
\hline & & & & \multirow{2}{*}{$\mathrm{f}$} & \multirow{2}{*}{100} & \multirow{2}{*}{1487.0} & \multirow{2}{*}{75.7} & 169.1 & 8.3 & $\mathrm{R}$ \\
\hline & & & & & & & & 169.1 & 8.3 & $\mathrm{~L}$ \\
\hline \multirow{4}{*}{ Uhrová et al. (2015) } & \multirow{4}{*}{ Slovakia } & \multirow{4}{*}{$\mathrm{A} / \mathrm{a}$} & \multirow{4}{*}{$18-24$} & \multirow{2}{*}{$\mathrm{m}$} & \multirow{2}{*}{120} & \multirow{2}{*}{1795.0} & \multirow{2}{*}{64.6} & 187.0 & 8.9 & $\mathrm{R}$ \\
\hline & & & & & & & & 187.3 & 9.2 & $\mathrm{~L}$ \\
\hline & & & & $f$ & 130 & 16638 & 618 & 172.1 & 7.5 & $\mathrm{R}$ \\
\hline & & & & 1 & 100 & 1005.0 & 01.0 & 172.1 & 7.6 & $\mathrm{~L}$ \\
\hline & & & & $f^{1}$ & 603 & 15136 & 446 & 162.7 & 8.1 & $\mathrm{R}$ \\
\hline Pal et al (2016) & India & $\mathrm{A} / \mathrm{a}$ & $20-40$ & & 095 & 1513.0 & 44.0 & 162.7 & 8.0 & $\mathrm{~L}$ \\
\hline Fal et di. $(2010)$ & 1mura & A/d & $20-40$ & $f$ & 896 & 15137 & 480 & 163.0 & 8.6 & $\mathrm{R}$ \\
\hline & & & & 1 & 890 & 1513.1 & & 163.1 & 8.5 & $\mathrm{~L}$ \\
\hline Mahakizadeh et al. (2016) & Iran & E/e & $18-25$ & $\mathrm{~m}$ & 146 & 1740.4 & 58.1 & 212.1 & 12.1 & $\mathrm{R}$ \\
\hline Paulis $(2015)$ & Foynt & $\mathrm{A} / \mathrm{d}$ & $18-67$ & $\mathrm{~m}$ & 100 & 1678.9 & 58.6 & 191.2 & 9.1 & $\mathrm{R}$ \\
\hline 1 auns $(2010)$ & Lgypt & A/ & $10-01$ & $\mathrm{f}$ & 91 & 1569.6 & 66.4 & 178.2 & 15.7 & $\mathrm{R}$ \\
\hline Jee and Yun $(2015)$ & South Korea & $\mathrm{F} / \mathrm{a}$ & $20-70$ & $\mathrm{~m}$ & 167 & 1696.0 & 63.5 & 183.0 & 9.0 & $\mathrm{R}$ \\
\hline Jee and run (2015) & South Korea & $\mathrm{E} / \mathrm{a}$ & $20-83$ & $\mathrm{f}$ & 154 & 1556.0 & 65.0 & 171.0 & 8.0 & $\mathrm{R}$ \\
\hline & Nigeria $^{2}$ & & & $\mathrm{~m}$ & 70 & 1747.9 & 72.0 & 206.2 & 10.9 & $\mathrm{R}$ \\
\hline & & & & $\mathrm{f}$ & 64 & 1670.3 & 83.2 & 198.5 & 14.4 & $\mathrm{R}$ \\
\hline Numan et al (2013) & Nigeria ${ }^{3}$ & $\mathrm{~B} / \mathrm{a}$ & $18-35$ & $\mathrm{~m}$ & 70 & 1715.8 & 102.9 & 202.2 & 12.5 & $\mathrm{R}$ \\
\hline (Numant et al. (2015) & Nigenia & $\mathrm{D} / \mathrm{a}$ & $10-53$ & $\mathrm{f}$ & 68 & 1694.0 & 60.2 & 199.7 & 8.2 & $\mathrm{R}$ \\
\hline & Nigeria 4 & & & $\mathrm{~m}$ & 70 & 1705.3 & 83.7 & 195.5 & 6.7 & $\mathrm{R}$ \\
\hline & Nigeria & & & $\mathrm{f}$ & 65 & 1640.5 & 64.5 & 192.7 & 10.5 & $\mathrm{R}$ \\
\hline Ahmed $(2013)$ & Sudan & $\mathrm{A} / \mathrm{a}$ & $25-30$ & $\mathrm{~m}$ & 100 & 1751.1 & 62.2 & 191.6 & 11.2 & $\mathrm{~L}$ \\
\hline Aнाпाеव (2015) & Sudant & $\mathrm{A} / \mathrm{d}$ & $25-50$ & $\mathrm{f}$ & 100 & 1602.5 & 57.1 & 172.5 & 8.7 & $\mathrm{~L}$ \\
\hline Özaslan et al (2012) & Turkey & $\mathrm{A} / \mathrm{c}$ & $20-51$ & $\mathrm{~m}$ & 224 & 1724.4 & 68.7 & 192.3 & 9.3 & $\mathrm{R}$ \\
\hline Uzasian et al. (2012) & rurkey & $\mathrm{A} / \mathrm{C}$ & $20-51$ & $\mathrm{f}$ & 132 & 1620.1 & 64.2 & 179.6 & 7.0 & $\mathrm{R}$ \\
\hline Krishan et al (2012) & India & F/e & $17-20$ & $\mathrm{~m}$ & 123 & 1682.0 & 65.0 & 182.0 & 9.0 & $\mathrm{~L}$ \\
\hline K & Hivia & L/ & $17-20$ & $\mathrm{f}$ & 123 & 1557.0 & 52.0 & 168.0 & 8.0 & $\mathrm{~L}$ \\
\hline
\end{tabular}

$\mathrm{M}$ - male, $\mathrm{f}$ - female, $\mathrm{N}$ - number of individuals, NA - not available, side - side of hand: $\mathrm{R}$ - right, $\mathrm{L}$ - left, $\mathrm{B}$ - both hands. Measuring instruments $\mathrm{H}$ (height): A - stadiometer; anthropometer; B - standing height measuring instrument and unspecified tool from anthropometric sets/kits; C - other tools: measuring tape, meter gauge, body meter, meter rule, metal tape; D - verbal information; E - NA. Measuring instruments HL (hand length): a - caliper, sliding caliper, Vernier caliper, digital caliper, spreading caliper, anthropometric rod Compass, segmometer, small metallic anthropometer, L - shaped scale; b - unspecified tool from anthropometric sets; $\mathrm{c}$ - standard measuring tape, calibrated non stretch tape; $\mathrm{d}$ - hand length was measured from: hand prints, outlines of the hand,

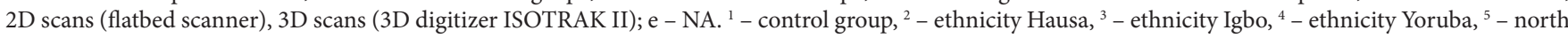
Indians, ${ }^{6}$ - south Indians, ${ }^{7}-$ Jat Sikh: a peasant tribe or caste of northern India and erstwhile Punjab now part of Pakistan, ${ }^{8}-$ south Indians, ${ }^{9}-$ north Indians, ${ }^{10}$ - volleyball players, ${ }^{11}$ - control group, ${ }^{12}$ - Bengali, ${ }^{13}$ - lower-southern, ${ }^{14}$ - southern, ${ }^{15}$ - Right-motor-sidedness, ${ }^{16}$ - Left-motor-sidedness, ${ }^{17}$ - study A, ${ }^{18}$ - study B, ${ }^{19}$ - Americans of Vietnamese origin, ${ }^{20}$ - hand prints, ${ }^{21}$ - athletes, ${ }^{22}$ - non-athletes, ${ }^{23}$ - Centro Hospitalar do Porto in Portugal: Caucasian, dev. sample, ${ }^{24}$ - Centro Hospitalar do Porto in Portugal, Caucasian, ${ }^{25}$ - Chinese sub-group, ${ }^{26}$ - workers in the maquiladora industry along the border of Mexico and the United States (US), ${ }^{27}$ - college students, ${ }^{28}$ - ICE (Institute of Consumer Ergonomics), 1983. Seating for elderly and disabled people. Report No. 2 . Anthropometric survey. Institute for Consumer Ergonomics, Loughborough, UK. 
Tab. 1. Complete table of applied population samples - hand and height measurements (continued).

\begin{tabular}{|c|c|c|c|c|c|c|c|c|c|c|}
\hline \multirow[b]{2}{*}{ Study } & \multirow[b]{2}{*}{ state } & \multirow{2}{*}{$\begin{array}{c}\text { measuring } \\
\text { instruments } \\
(\mathrm{H} / \mathrm{HL}) \\
\end{array}$} & \multirow[b]{2}{*}{ age } & \multirow[b]{2}{*}{$\operatorname{sex}$} & \multirow[b]{2}{*}{$\mathbf{N}$} & \multicolumn{2}{|c|}{ height } & \multicolumn{3}{|c|}{ hand lenght } \\
\hline & & & & & & mean & sd & mean & sd & side \\
\hline \multirow{4}{*}{ Ishak et al. (2012) } & \multirow{4}{*}{ Australia } & \multirow{4}{*}{$\mathrm{A} / \mathrm{a}$} & \multirow{2}{*}{$19-68$} & \multirow{2}{*}{$\mathrm{m}$} & \multirow{2}{*}{91} & \multirow{2}{*}{1785.0} & \multirow{2}{*}{70.5} & 195.4 & 9.3 & $\mathrm{R}$ \\
\hline & & & & & & & & 195.6 & 9.2 & $\mathrm{~L}$ \\
\hline & & & \multirow{2}{*}{$18-63$} & $\mathrm{f}$ & 110 & 16370 & 714 & 175.9 & 8.2 & $\mathrm{R}$ \\
\hline & & & & 1 & & 1051.0 & 11.4 & 176.0 & 8.2 & $\mathrm{~L}$ \\
\hline Akhlaghi et al (2012) & Iran & $E / a$ & $21-26$ & $\mathrm{~m}$ & 50 & 1760.0 & 60.0 & 189.3 & 14.2 & $\mathrm{~L}$ \\
\hline (2) & 11all & & & $\mathrm{f}$ & 50 & 1620.0 & 60.0 & 171.5 & 9.2 & $\mathrm{~L}$ \\
\hline Krishan et al (2010) & India & $\mathrm{E} / \mathrm{e}$ & $18-30$ & $m$ & 967 & 17254 & 668 & 180.6 & 9.4 & $\mathrm{R}$ \\
\hline (2) & mera & L/ & & & & 1720.7 & & 185.3 & 9.7 & $\mathrm{~L}$ \\
\hline & & & & $\mathrm{m}$ & 82 & 1746.1 & 73.4 & 192.9 & 8.4 & $\mathrm{R}$ \\
\hline Habib and Kamal (2010) & Egypt & $\mathrm{A} / \mathrm{a}$ & $18-25$ & & & & & 193.6 & 8.6 & $\mathrm{~L}$ \\
\hline & & & & $\mathrm{f}$ & 77 & 1600.0 & 54.5 & 176.0 & 8.0 & $\mathrm{R}$ \\
\hline & & & & & & & & 176.2 & 7.7 & \\
\hline & & & & $\mathrm{m}$ & 120 & 1716.0 & 66.2 & 188.9 & 9.1 & $\mathrm{R}$ \\
\hline & India $^{5}$ & & & & & & & 188.7 & 9.1 & $\mathrm{~L}$ \\
\hline & & & & $\mathrm{f}$ & 100 & 1586.6 & 60.6 & 170.3 & 9.4 & $\mathrm{R}$ \\
\hline Rastogi et al. (2008) & & $\mathrm{A} / \mathrm{a}$ & $20-30$ & & & & & 170.1 & 9.5 & $\mathrm{~L}$ \\
\hline & & & & $\mathrm{m}$ & 110 & 1719.5 & 70.5 & 188.2 & 9.5 & $\mathrm{R}$ \\
\hline & India $^{6}$ & & & & & & & 188.1 & 9.6 & $\mathrm{~L}$ \\
\hline & & & & $\mathrm{f}$ & 170 & 1585.7 & 51.0 & 169.7 & 7.8 & $\mathrm{R}$ \\
\hline & & & & & & & & 169.5 & 7.5 & $\mathrm{~L}$ \\
\hline & & & & $\mathrm{m}$ & 125 & 1739.9 & 61.3 & 188.9 & 8.8 & $\mathrm{R}$ \\
\hline Agnihotri et al. (2008) & Mauritius & $\mathrm{A} / \mathrm{a}$ & $18-30$ & & & & & 189.0 & 8.7 & $\mathrm{~L}$ \\
\hline & & & & $\mathrm{f}$ & 125 & 1595.6 & 62.5 & 172.2 & 9.2 & $\mathrm{R}$ \\
\hline & & & & & & & & 172.2 & 9.3 & $\mathrm{~L}$ \\
\hline & & & & $\mathrm{m}$ & 123 & 1682.4 & 650 & 182.4 & 9.0 & $\mathrm{R}$ \\
\hline Krishan and Sharma (2007) & India & $\mathrm{A} / \mathrm{a}$ & $17-20$ & & & & & 182.1 & 9.1 & $\mathrm{~L}$ \\
\hline & & & & $f$ & 123 & 15572 & 51.8 & 168.3 & 8.0 & $\mathrm{R}$ \\
\hline & & & & 1 & $12 J$ & 1031.2 & 51.0 & 168.0 & 8.3 & $\mathrm{~L}$ \\
\hline & & & & $\mathrm{m}$ & 30 & 17520 & 524 & 198.0 & 7.3 & $\mathrm{R}$ \\
\hline Jasuja and Singh (2004) & India/Pakistan ${ }^{7}$ & $\mathrm{~A} / \mathrm{a}$ & $18-60$ & 111 & 30 & 1752.0 & 52.4 & 197.9 & 7.6 & $\mathrm{~L}$ \\
\hline & & & & $f$ & 30 & 15970 & 517 & 175.1 & 8.1 & $\mathrm{R}$ \\
\hline & & & & & & 1091.0 & & 174.7 & 8.0 & $\mathrm{~L}$ \\
\hline & & & & $\mathrm{m}$ & 72 & 17595 & 502 & 188.9 & 11.2 & $\mathrm{R}$ \\
\hline Patel et al. (2014) & India & $\mathrm{E} / \mathrm{a}$ & $18-22$ & & & & & 188.6 & 11.2 & $\mathrm{~L}$ \\
\hline & & & & $f$ & 78 & 16086 & 560 & 171.1 & 10.3 & $\mathrm{R}$ \\
\hline & & & & 1 & 10 & 1000.0 & 50.0 & 170.8 & 10.3 & $\mathrm{~L}$ \\
\hline & & & & $\mathrm{m}$ & 112 & 17265 & 725 & 188.9 & 8.8 & $\mathrm{R}$ \\
\hline Jaiswal (N. D.) & India & $\mathrm{A} / \mathrm{a}$ & $18-31$ & & & & & 189.0 & 8.7 & $\mathrm{~L}$ \\
\hline (D.) & mura & $\mathbf{N} / \mathbf{a}$ & $10-51$ & $f$ & & 15846 & 685 & 172.2 & 9.2 & $\mathrm{R}$ \\
\hline & & & & & 103 & 1584.0 & 08.5 & 172.2 & 9.3 & $\mathrm{~L}$ \\
\hline & & & & & 50 & 17158 & & 181.8 & 8.7 & $\mathrm{R}$ \\
\hline Laulathaphol et al (2013) & Thailand & $\mathrm{A} / \mathrm{a}$ & $18-26$ & $\mathrm{~m}$ & 50 & 1715.8 & 44.1 & 181.3 & 8.0 & $\mathrm{~L}$ \\
\hline & H Hananu & $\mathbf{H} / \mathbf{a}$ & $10-20$ & $f$ & 50 & 15963 & 528 & 166.8 & 8.6 & $\mathrm{R}$ \\
\hline & & & & 1 & 50 & 1590.3 & 52.8 & 166.0 & 9.2 & $\mathrm{~L}$ \\
\hline Kaur et al. (2013) & India & $\mathrm{A} / \mathrm{a}$ & $17-25$ & $\mathrm{~m}$ & 200 & 1759.8 & 67.6 & 188.0 & 10.9 & $\mathrm{~L}$ \\
\hline Kaur et al. (2013) & India & $\mathrm{A} / \mathrm{a}$ & $1 /-25$ & $\mathrm{f}$ & 200 & 1609.1 & 57.5 & 185.4 & 10.7 & $\mathrm{~L}$ \\
\hline & & & & & & & & 186.8 & 6.9 & $\mathrm{R}$ \\
\hline & & & $22-86$ & $\mathrm{~m}$ & 250 & 1635.4 & 52.2 & 185.4 & 6.8 & $\mathrm{~L}$ \\
\hline Goswami et al. (2016) & India & $\mathrm{C} / \mathrm{a}$ & & & & & & 186.0 & 6.8 & B \\
\hline Goswami et al. (2016) & India & $\mathrm{c} / \mathrm{a}$ & & & & & & 164.7 & 0.7 & $\mathrm{R}$ \\
\hline & & & $22-70$ & $\mathrm{f}$ & 250 & 1556.9 & 101.3 & 162.7 & 6.9 & $\mathrm{~L}$ \\
\hline & & & & & & & & 163.9 & 7.0 & B \\
\hline
\end{tabular}


Tab. 1. Complete table of applied population samples - hand and height measurements (continued).

\begin{tabular}{|c|c|c|c|c|c|c|c|c|c|c|}
\hline \multirow[b]{2}{*}{ Study } & \multirow[b]{2}{*}{ state } & \multirow{2}{*}{$\begin{array}{c}\text { measuring } \\
\text { instruments } \\
(\mathrm{H} / \mathrm{HL})\end{array}$} & \multirow[b]{2}{*}{ age } & \multirow[b]{2}{*}{ sex } & \multirow[b]{2}{*}{$\mathbf{N}$} & \multicolumn{2}{|c|}{ height } & \multicolumn{3}{|c|}{ hand lenght } \\
\hline & & & & & & mean & sd & mean & sd & side \\
\hline \multirow{6}{*}{ Wakode et al. (2015) } & \multirow{6}{*}{ India } & \multirow{6}{*}{$\mathrm{A} / \mathrm{a}$} & \multirow{6}{*}{$17-25$} & \multirow{4}{*}{$\mathrm{m}$} & \multirow{4}{*}{94} & \multirow{4}{*}{1714.6} & \multirow{4}{*}{57.9} & 183.1 & 8.7 & $\mathrm{R}$ \\
\hline & & & & & & & & 183.7 & 9.4 & $\mathrm{~L}$ \\
\hline & & & & & & & & 183.4 & 9.0 & B \\
\hline & & & & & & & & 167.2 & 7.7 & $\mathrm{R}$ \\
\hline & & & & $\mathrm{f}$ & 106 & 1576.6 & 53.7 & 166.8 & 7.7 & $\mathrm{~L}$ \\
\hline & & & & & & & & 167.0 & 7.7 & B \\
\hline & & & & $m$ & 100 & 16557 & 659 & 179.8 & 9.5 & $\mathrm{R}$ \\
\hline Varu et al (2015) & India & $\mathrm{C} / \mathrm{a}$ & over 20 & III & & 1053.1 & & 178.0 & 9.8 & $\mathrm{~L}$ \\
\hline varu te al. $(2010)$ & Minia & $\mathrm{C} / \mathrm{d}$ & Over 20 & $f$ & 100 & 15102 & 560 & 166.5 & 8.4 & $\mathrm{R}$ \\
\hline & & & & 1 & 100 & 1000.2 & 50.9 & 165.7 & 8.7 & $\mathrm{~L}$ \\
\hline Chandra et al. (2015) & India & $\mathrm{A} / \mathrm{a}$ & $18-62$ & $\mathrm{~m}$ & 1540 & 1640.8 & 73.1 & 186.5 & 8.1 & $\mathrm{R}$ \\
\hline & & & & $\mathrm{m}$ & 109 & 17173 & 682 & 188.1 & 11.2 & $\mathrm{R}$ \\
\hline & India ${ }^{8}$ & & & 111 & 107 & $1711 / .0$ & & 187.4 & 14.7 & $\mathrm{~L}$ \\
\hline & & & & $\mathrm{f}$ & 129 & 1592.5 & 62.1 & 171.7 & 9.3 & $\mathrm{R}$ \\
\hline Kavyashree et al. (2015) & & $\mathrm{A} / \mathrm{a}$ & $20-22$ & & & & & 172.1 & 9.0 & $\mathrm{~L}$ \\
\hline & & & & $\mathrm{m}$ & 33 & 1690.4 & 54.9 & 189.5 & 13.2 & $\mathrm{R}$ \\
\hline & India $^{9}$ & & & & & & & 187.0 & 21.3 & $\mathrm{~L}$ \\
\hline & & & & $\mathrm{f}$ & 33 & 1584.2 & 52.0 & 173.0 & 10.6 & $\mathrm{R}$ \\
\hline Sanli et al $(2005)$ & Turkey & $B / a$ & $17-23$ & $\mathrm{~m}$ & 80 & 1750.6 & 61.3 & 208.8 & 9.2 & $\mathrm{R}$ \\
\hline sannl el al. (2000) & rurkey & $\mathrm{B} / \mathrm{d}$ & $1 /-23$ & $\mathrm{f}$ & 75 & 1599.6 & 49.2 & 189.6 & 9.3 & $\mathrm{R}$ \\
\hline & & & & $\mathrm{m}$ & 75 & 16900 & 780 & 196.0 & 13.0 & $\mathrm{R}$ \\
\hline Sunil et al. (2005) & India & $\mathrm{A} / \mathrm{a}$ & $18-22$ & 111 & & & & 195.0 & 12.0 & $\mathrm{~L}$ \\
\hline & & & & $\mathrm{f}$ & 75 & 1580.0 & 58.0 & 182.0 & 10.0 & $\mathrm{R}$ \\
\hline & & & & & & & & 181.0 & 10.0 & $\mathrm{~L}$ \\
\hline Saxena (1984) & Nioeria & $\mathrm{A} / \mathrm{e}$ & $20-30$ & $m$ & 100 & 16845 & 763 & 192.9 & 6.6 & $\mathrm{R}$ \\
\hline Saxena $(1904)$ & Nigeria & $\mathrm{A} / \mathrm{e}$ & $20-50$ & $\mathrm{~m}$ & 100 & 1084.3 & 10.3 & 194.1 & 7.4 & $\mathrm{~L}$ \\
\hline & & & & $\mathrm{f}^{10}$ & 101 & 1647.8 & 40.0 & 181.3 & 8.0 & $\mathrm{R}$ \\
\hline Koley and Kaur (2011) & India & $\mathrm{A} / \mathrm{a}$ & $18-25$ & & & & & 180.8 & 8.0 & $\mathrm{~L}$ \\
\hline & & & & $f^{11}$ & 100 & 1594.1 & 48.2 & 170.3 & 6.8 & $\mathrm{R}$ \\
\hline & & & & & & & & 170.3 & 6.7 & $\mathrm{~L}$ \\
\hline & & & & $\mathrm{m}$ & 187 & 1750.0 & 60.0 & 187.1 & 8.3 & $\mathrm{R}$ \\
\hline Barut et al. (2014) & Turkey & $\mathrm{C} / \mathrm{a}$ & $20-41$ & & & & & 187.2 & 9.3 & $\mathrm{~L}$ \\
\hline & & & & $\mathrm{f}$ & 198 & 1610.0 & 60.0 & 171.4 & 8.0 & $\mathrm{R}$ \\
\hline & & & & & & & & 184.6 & 11.3 & $\mathrm{R}$ \\
\hline Sunore et al (2015) & India & $\Delta / a_{1}+2-1$ & $18-24$ & $\mathrm{~m}$ & 219 & 1707.5 & 94.7 & 184.2 & 11.4 & $\mathrm{~L}$ \\
\hline supare et al. (2015) & India & $\mathrm{A} / \mathrm{a}$ & $18-24$ & $f$ & 181 & 15046 & 766 & 172.5 & 10.5 & $\mathrm{R}$ \\
\hline & & & & $\mathrm{T}$ & 181 & 1594.6 & 10.6 & 172.2 & 10.6 & $\mathrm{~L}$ \\
\hline & & & mean 24,50 & $m$ & 250 & 17330 & 713 & 198.5 & 8.6 & $\mathrm{R}$ \\
\hline Danborno and Elukpo & Nigeria & $\mathrm{A} / \mathrm{a}$ & $(\mathrm{sd} 2,82)$ & 111 & & & 11.0 & 199.3 & 9.3 & $\mathrm{~L}$ \\
\hline$(2008)$ & & & mean 22,22 & $f$ & 150 & 16000 & 622 & 185.1 & 6.6 & $\mathrm{R}$ \\
\hline & & & $(\mathrm{sd} 2,00)$ & $\mathrm{t}$ & 150 & 1000.0 & 02.2 & 185.2 & 7.7 & $\mathrm{~L}$ \\
\hline Waghmare et al. (2010) & India & $\mathrm{A} / \mathrm{a}$ & over 25 & $\mathrm{~m}$ & 200 & 1590.1 & 67.8 & 169.2 & 9.1 & $\mathrm{R}$ \\
\hline & & & & & & & & 164.6 & 9.3 & $\mathrm{~L}$ \\
\hline & & & & $\mathrm{m}$ & 50 & 16794 & 757 & 186.0 & 6.4 & $\mathrm{R}$ \\
\hline Nagesh et al. (2014) & India & $\mathrm{A} / \mathrm{e}$ & NA & & & & & 186.8 & 7.7 & $\mathrm{~L}$ \\
\hline & & & & $f$ & 50 & 15533 & 532 & 170.5 & 8.9 & $\mathrm{R}$ \\
\hline & & & & 1 & 50 & 1553.3 & 53.2 & 172.3 & 7.7 & $\mathrm{~L}$ \\
\hline Laila et al. (2009) & India ${ }^{12}$ & $\mathrm{~A} / \mathrm{a}$ & $25-30$ & $\mathrm{f}$ & 150 & 1560.2 & 613 & 163.9 & 7.9 & $\mathrm{R}$ \\
\hline & & & & & & & & 163.4 & 8.0 & $\mathrm{~L}$ \\
\hline & & & & $m$ & 100 & 16930 & 100 & 182.0 & 19.0 & $\mathrm{R}$ \\
\hline Mohamed (2013) & Egypt & E/a & $25-30$ & & & & & 179.4 & 5.0 & $\mathrm{~L}$ \\
\hline & & & & $\mathrm{f}$ & 100 & 1594.0 & 53.0 & 169.0 & 7.9 & $\mathrm{R}$ \\
\hline Chandra et al (30 & & & & & & & & 160.2 & 7.6 & $\mathrm{~L}$ \\
\hline Chandra et al. (20 & India & $\mathrm{A} / \mathrm{a}$ & $18-62$ & $\mathrm{~m}$ & 1540 & 1641.0 & 73.1 & 186.5 & 8.1 & $\mathrm{R}$ \\
\hline
\end{tabular}


Tab. 1. Complete table of applied population samples - hand and height measurements (continued).

\begin{tabular}{|c|c|c|c|c|c|c|c|c|c|c|}
\hline \multirow[b]{2}{*}{ Study } & \multirow[b]{2}{*}{ state } & \multirow{2}{*}{$\begin{array}{c}\text { measuring } \\
\text { instruments } \\
(\mathbf{H} / \mathbf{H L})\end{array}$} & \multirow[b]{2}{*}{ age } & \multirow[b]{2}{*}{ sex } & \multirow[b]{2}{*}{$\mathbf{N}$} & \multicolumn{2}{|c|}{ height } & \multicolumn{3}{|c|}{ hand lenght } \\
\hline & & & & & & mean & sd & mean & sd & side \\
\hline \multirow{4}{*}{$\begin{array}{l}\text { Moorthy and Zulkifly } \\
\qquad(2014)\end{array}$} & \multirow{4}{*}{ Malaysia } & \multirow{4}{*}{$\mathrm{C} / \mathrm{a}$} & \multirow{4}{*}{$18-60$} & \multirow{2}{*}{$\mathrm{m}$} & \multirow{2}{*}{100} & \multirow{2}{*}{1687.0} & \multirow{2}{*}{60.0} & 186.0 & 9.0 & $\mathrm{R}$ \\
\hline & & & & & & & & 187.0 & 9.0 & $\mathrm{~L}$ \\
\hline & & & & \multirow{2}{*}{$\mathrm{f}$} & \multirow{2}{*}{100} & 15630 & 600 & 170.0 & 9.0 & $\mathrm{R}$ \\
\hline & & & & & & & 00.0 & 169.0 & 8.0 & $\mathrm{~L}$ \\
\hline Bouabdallah (2012) & Algeria & $\mathrm{A} / \mathrm{a}$ & $66-81$ & $\mathrm{~m}$ & 60 & 1716.0 & 76.0 & 193.0 & 14.0 & $\mathrm{R}$ \\
\hline Mandahowi et al (2008) & Jordan & $\mathrm{F} / \mathrm{a}$ & $18-50$ & $\mathrm{~m}$ & 115 & 1767.8 & 73.9 & 191.2 & 10.2 & $\mathrm{R}$ \\
\hline 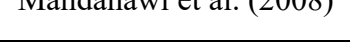 & Joluall & $\mathrm{L} / \mathrm{d}$ & $10-59$ & $\mathrm{f}$ & 120 & 1621.9 & 52.0 & 171.3 & 7.4 & $\mathrm{R}$ \\
\hline & Thailand & & & $\mathrm{m}$ & 50 & 1691.7 & 56.0 & 179.8 & 14.6 & $\mathrm{R}$ \\
\hline Klamklay et al $(2008)$ & & $\mathrm{B} / \mathrm{h}$ & $18-25$ & $\mathrm{f}$ & 50 & 1569.0 & 48.5 & 166.3 & 7.2 & $\mathrm{R}$ \\
\hline 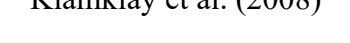 & Thailand & $\mathrm{B} / \mathrm{D}$ & $18-25$ & $\mathrm{~m}$ & 100 & 1719.4 & 51.5 & 191.1 & 71.6 & $\mathrm{R}$ \\
\hline & & & & $\mathrm{f}$ & 100 & 1579.4 & 53.2 & 166.1 & 7.3 & $\mathrm{R}$ \\
\hline & & & 31,23 & $\mathrm{~m}^{15}$ & $200 /$ & 17080 & 540 & 178.3 & 6.4 & $\mathrm{R}$ \\
\hline & & & $(\operatorname{sd~6,7)}$ & III & 100 & 1700.0 & 34.0 & 173.1 & 8.6 & $\mathrm{~L}$ \\
\hline & & & 29,07 & $f^{15}$ & $200 /$ & 16280 & 800 & 162.3 & 5.4 & $\mathrm{R}$ \\
\hline Mohammad (2005) & Jordan & $\mathrm{E} / \mathrm{a}$ & $(\operatorname{sd~8,3)}$ & & 100 & 1028.0 & 89.0 & 161.7 & 4.9 & $\mathrm{~L}$ \\
\hline 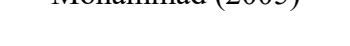 & 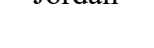 & $\mathrm{L} / \mathrm{a}$ & 31,23 & $\mathrm{~m}^{16}$ & $200 /$ & 1708.0 & 54.0 & 172.1 & 3.7 & $\mathrm{R}$ \\
\hline & & & $(\mathrm{sd} 6,7)$ & & 100 & & & 172.8 & 5.3 & $\mathrm{~L}$ \\
\hline & & & 29,07 & $f^{16}$ & $200 /$ & 16280 & 890 & 161.5 & 4.9 & $\mathrm{R}$ \\
\hline & & & $(\mathrm{sd} 8,3)$ & & & & & 161.9 & 5.4 & $\mathrm{~L}$ \\
\hline Dewangan et al. (2008) & India & $\mathrm{A} / \mathrm{a}$ & $18-60$ & $\mathrm{f}$ & 400 & 1532.5 & 55.0 & 165.3 & 7.3 & $\mathrm{R}$ \\
\hline Eksioglu (2004) & NA & $\mathrm{E} / \mathrm{e}$ & $21-33$ & $\mathrm{~m}$ & 12 & 1753.5 & 54.2 & 193.5 & 6.7 & $\mathrm{R}$ \\
\hline Mokdad (2002) & Algeria & $\mathrm{A} / \mathrm{a}$ & $15-75$ & $\mathrm{~m}$ & 514 & 1726.0 & 76.0 & 194.0 & 14.0 & $\mathrm{R}$ \\
\hline $\begin{array}{c}\text { Vyavahare and Kallurkar } \\
(2016)\end{array}$ & India & $\mathrm{A} / \mathrm{a}$ & $18-60$ & $\mathrm{~m}$ & 303 & 1647.0 & 60.0 & 180.0 & 9.0 & $\mathrm{R}$ \\
\hline & & & & $\mathrm{m}$ & 67 & 17890 & 620 & 194.0 & 9.0 & $\mathrm{R}$ \\
\hline & Sweden ${ }^{17}$ & & & & & & & 194.0 & 9.0 & $\mathrm{~L}$ \\
\hline & & & & $f$ & 201 & 16770 & 680 & 181.0 & 9.0 & $\mathrm{R}$ \\
\hline Hanson et al. (2009) & & $\mathrm{C} / \mathrm{c} ?$ & $18-65$ & & & & & 180.0 & 9.0 & $\mathrm{~L}$ \\
\hline & & & & $\mathrm{m}$ & 38 & 1796.0 & 83.0 & 192.0 & 10.0 & $\mathrm{R}$ \\
\hline & Sweden ${ }^{18}$ & & & & & & & 194.0 & 10.0 & $\mathrm{~L}$ \\
\hline & & & & $\mathrm{f}$ & 61 & 1663.0 & 66.0 & 174.0 & 8.0 & $\mathrm{R}$ \\
\hline & & & & & & & & 176.0 & 9.0 & $\mathrm{~L}$ \\
\hline Khadem and Islam (2014) & Bangladesh & $\mathrm{A} / \mathrm{a}$ & $15-64$ & $\mathrm{~m}$ & 470 & 1677.0 & 52.5 & 196.0 & 11.7 & $\mathrm{R}$ \\
\hline Dewangan et al. (2010) & India & $\mathrm{B} / \mathrm{b}$ & $18-60$ & $\mathrm{~m}$ & 800 & 1620.0 & 60.0 & 175.0 & 10.0 & $\mathrm{R}$ \\
\hline Imrhan et al (1993) & USA 19 & $\mathrm{~F} / \mathrm{a}$ & $17-561$ & $\mathrm{~m}$ & 41 & 1646.0 & 53.6 & 177.0 & 12.0 & $\mathrm{R}$ \\
\hline & & & $1 /-50,1$ & $\mathrm{f}$ & 30 & 1559.0 & 61.0 & 165.0 & 9.0 & $\mathrm{R}$ \\
\hline $\begin{array}{c}\text { Saengchaiya and } \\
\text { Bunterngchit (2004) }\end{array}$ & Thailand & $\mathrm{E} / \mathrm{d}$ & $\begin{array}{c}25,1 \\
(\operatorname{sd~} 5,4)\end{array}$ & $\mathrm{f}$ & 150 & 1553.0 & 56.0 & 177.2 & 7.0 & $\mathrm{R}$ \\
\hline Nag et al. (2003) & India & $\mathrm{E} / \mathrm{a}$ & $16-58$ & $\mathrm{f}$ & 95 & 1498.8 & 62.8 & 169.6 & 9.4 & $\mathrm{R}$ \\
\hline & & & & $\mathrm{m}$ & 40 & 16300 & 510 & 189.0 & 31.0 & $\mathrm{R}$ \\
\hline Subashri and Thenmozhi & India & $\mathrm{E} / \mathrm{e}$ & $18-23$ & & & & 31.0 & 185.0 & 30.0 & $\mathrm{~L}$ \\
\hline & & & & $f$ & 60 & 16000 & 58.0 & 165.0 & 28.0 & $\mathrm{R}$ \\
\hline & & & & & 00 & 1000.0 & 30.0 & 161.0 & 27.0 & $\mathrm{~L}$ \\
\hline Jlayneruma et al (2009) & Sri Ianka & $\mathrm{B} / \mathrm{a}$ & $20-23$ & $\mathrm{~m}$ & 140 & 1701.4 & 52.2 & 190.1 & 8.6 & $\mathrm{~B}$ \\
\hline 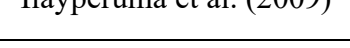 & SII Lanka & $\mathrm{B} / \mathrm{a}$ & $20-23$ & $\mathrm{f}$ & 118 & 1575.5 & 57.5 & 176.2 & 9.3 & $\mathrm{~B}$ \\
\hline & Saudi & & & $\mathrm{m}$ & 100 & 1715.0 & 51.0 & 181.0 & 10.2 & $\mathrm{~B}$ \\
\hline Kornieieva and Elelemi & Arabia & $\mathrm{A} / \mathrm{d}$ & $18-26$ & $\mathrm{f}$ & 100 & 1593.0 & 63.6 & 170.6 & 7.2 & $\mathrm{~B}$ \\
\hline$(2016)$ & Saudi & $\mathrm{A} / \mathrm{U}$ & $10-20$ & $\mathrm{~m}$ & 100 & 1715.0 & 51.0 & 173.3 & 8.2 & B \\
\hline & Arabia $^{20}$ & & & $\mathrm{f}$ & 100 & 1593.0 & 63.6 & 163.1 & 7.6 & $\mathrm{~B}$ \\
\hline Oria et al (2016) & Nigeria & $\mathrm{C} / \mathrm{a}$ & $18-45$ & $\mathrm{~m}$ & 540 & 1684.9 & 55.3 & 194.7 & 20.0 & $\mathrm{~B}$ \\
\hline & & Cla & & $\mathrm{f}$ & 510 & 1629.9 & 59.1 & 183.5 & 10.3 & $\mathrm{~B}$ \\
\hline
\end{tabular}


Tab. 1. Complete table of applied population samples - hand and height measurements (continued).

\begin{tabular}{|c|c|c|c|c|c|c|c|c|c|c|}
\hline \multirow{2}{*}{ Study } & \multirow[b]{2}{*}{ state } & \multirow{2}{*}{$\begin{array}{c}\text { measuring } \\
\text { instruments } \\
(\mathrm{H} / \mathrm{HL})\end{array}$} & \multirow[b]{2}{*}{ age } & \multirow[b]{2}{*}{$\operatorname{sex}$} & \multirow[b]{2}{*}{$\mathbf{N}$} & \multicolumn{2}{|c|}{ height } & \multicolumn{3}{|c|}{ hand lenght } \\
\hline & & & & & & mean & sd & mean & sd & side \\
\hline \multirow{2}{*}{$\begin{array}{l}\text { Häger-Ross and Rösblad } \\
\text { (2002) }\end{array}$} & \multirow{2}{*}{ Sweden } & \multirow{2}{*}{$\mathrm{E} / \mathrm{d}$} & \multirow{2}{*}{16} & $\mathrm{~m}$ & 22 & 1799.0 & 55.0 & 196.0 & 10.0 & B \\
\hline & & & & $\mathrm{f}$ & 16 & 1672.0 & 50.0 & 176.0 & 8.0 & $\mathrm{~B}$ \\
\hline $\begin{array}{c}\text { Visnapuu and Jürimäe } \\
(2007)\end{array}$ & Estonia & $\mathrm{A} / \mathrm{d}$ & $16-17$ & $\mathrm{~m}$ & 21 & 1766.0 & 77.0 & 200.0 & 10.0 & B \\
\hline \multirow{2}{*}{$\begin{array}{c}\text { Fallahi and Jadidian } \\
\text { (2011) }\end{array}$} & \multirow{2}{*}{ NA } & \multirow{2}{*}{$\mathrm{A} / \mathrm{d}$} & \multirow{2}{*}{$19-29$} & $\mathrm{~m}^{21}$ & 40 & 1820.0 & 101.2 & 202.1 & 13.5 & $\mathrm{~B}$ \\
\hline & & & & & 40 & 1770.4 & 69.0 & 193.3 & 9.5 & $\mathrm{~B}$ \\
\hline \multirow{4}{*}{ Guerra et al. (2014) } & \multirow{2}{*}{ Portugal $^{23}$} & \multirow{4}{*}{$\mathrm{C} / \mathrm{a}$} & \multirow{4}{*}{$19-91$} & $\mathrm{~m}$ & 173 & 1698.0 & 79.0 & 183.0 & 9.0 & B \\
\hline & & & & $\mathrm{f}$ & 138 & 1567.0 & 71.0 & 169.0 & 9.0 & B \\
\hline & Posrtugal & & & $\mathrm{m}$ & 87 & 1693.0 & 68.0 & 183.0 & 8.0 & $\mathrm{~B}$ \\
\hline & & & & $\mathrm{f}$ & 67 & 1562.0 & 69.0 & 168.0 & 8.0 & $\mathrm{~B}$ \\
\hline Uobem et al (2016) & Nigeria & $\mathrm{B} / \mathrm{a}$ & $18-45$ & $\mathrm{~m}$ & 121 & 1705.0 & 60.7 & 185.9 & 9.7 & $\mathrm{~B}$ \\
\hline Ugentil et al. (2010) & Nigerid & $\mathrm{D} / \mathrm{d}$ & $10-45$ & $\mathrm{f}$ & 117 & 1622.0 & 61.1 & 177.4 & 11.6 & $\mathrm{~B}$ \\
\hline Hamid et al $(2015)$ & India & $\mathrm{A} / \mathrm{c}$ & $17-23$ & $\mathrm{~m}$ & 50 & 1736.0 & 50.0 & 192.4 & 8.0 & B \\
\hline Hamid et al. (2015) & India & $\mathrm{A} / \mathrm{c}$ & $1 /-23$ & $\mathrm{f}$ & 50 & 1562.4 & 71.0 & 178.9 & 8.5 & $\mathrm{~B}$ \\
\hline Tandon et al (2016) & India & $\mathrm{A} / \mathrm{a}$ & $18-30$ & $\mathrm{~m}$ & 238 & 1727.4 & 61.1 & 193.6 & 11.0 & B \\
\hline Iandon et al. $(2010)$ & 1miala & $\mathrm{A} / \mathrm{d}$ & $10-50$ & $\mathrm{f}$ & 259 & 1572.0 & 62.4 & 173.3 & 10.0 & $\mathrm{~B}$ \\
\hline & Molavsia & & & $\mathrm{m}$ & 50 & 1785.7 & 29.6 & 199.8 & 13.3 & $\mathrm{~B}$ \\
\hline & Malaysıa & & & $\mathrm{f}$ & 50 & 1533.0 & 95.4 & 169.5 & 11.9 & B \\
\hline Karmegan et al (2011) & Ching & F/e & $18-24$ & $\mathrm{~m}$ & 50 & 1693.8 & 59.1 & 182.2 & 13.3 & B \\
\hline Nadmegant et dil. (2011) & Cnina & $\mathrm{E} / \mathrm{e}$ & $18-24$ & $\mathrm{f}$ & 50 & 1585.8 & 51.4 & 171.7 & 11.3 & B \\
\hline & India & & & $\mathrm{m}$ & 50 & 1681.0 & 76.8 & 185.1 & 13.1 & B \\
\hline & India & & & $\mathrm{f}$ & 50 & 1568.3 & 67.9 & 173.1 & 11.8 & $\mathrm{~B}$ \\
\hline Molenhroek (1087) & Netherlands & 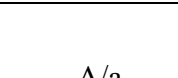 & $50-100$ & $\mathrm{~m}$ & $\begin{array}{l}152 / \\
197\end{array}$ & 1656.0 & 82.0 & 184.0 & 12.0 & B \\
\hline Miorenoroek (198/) & Netherrands & $\mathrm{A} / \mathrm{a}$ & $50-100$ & $\mathrm{f}$ & $\begin{array}{r}457 / \\
621 \\
\end{array}$ & 1543.0 & 72.0 & 172.0 & 10.0 & B \\
\hline & Indonesia & & & $\mathrm{m}$ & 245 & 1720.0 & 62.3 & 190.0 & 16.4 & B \\
\hline & & $\mathrm{A} / \mathrm{h}$ & $18-45$ & $\mathrm{f}$ & 132 & 1590.0 & 57.6 & 180.0 & 17.2 & B \\
\hline & & $\mathrm{A} / \mathrm{U}$ & $18-45$ & $\mathrm{~m}$ & 88 & 1710.0 & 48.1 & 190.0 & 24.2 & B \\
\hline Chuan et al (2010) & montes & & & $\mathrm{f}$ & 54 & 1590.0 & 50.6 & 180.0 & 21.6 & $\mathrm{~B}$ \\
\hline & Singapore & & & $\mathrm{m}$ & 138 & 1740.0 & 51.7 & 190.0 & 33.4 & B \\
\hline & Singapore & $\mathrm{P} / \mathrm{h}$ & 18,15 & $\mathrm{f}$ & 57 & 1620.0 & 36.6 & 170.0 & 5.5 & B \\
\hline & Singapore & $\mathrm{B} / \mathrm{b}$ & $18-45$ & $\mathrm{~m}$ & 104 & 1730.0 & 54.5 & 190.0 & 27.3 & B \\
\hline & & & & $\mathrm{f}$ & 47 & 1620.0 & 36.9 & 170.0 & 5.7 & $\mathrm{~B}$ \\
\hline $\begin{array}{l}\text { García-Cáceres et al. } \\
\text { (2012) }\end{array}$ & Colombia & $\mathrm{E} / \mathrm{a}$ & $\begin{array}{c}\text { mean } \\
41,2 \\
(\operatorname{sd} 8,3)\end{array}$ & $\mathrm{f}$ & 120 & 1546.0 & 96.0 & 167.3 & 8.0 & B \\
\hline & & & below & $\mathrm{m}$ & 843 & 1670.1 & 80.3 & 197.5 & 78.2 & B \\
\hline Del Prado-Lu (2007) & Philippines & $\mathrm{A} / \mathrm{e}$ & $\begin{array}{l}\text { years } \\
(77 \%)\end{array}$ & $\mathrm{f}$ & 962 & 1539.2 & 82.8 & 179.5 & 34.4 & B \\
\hline Liu et al. (1999) & $\begin{array}{l}\text { Mexico/ } \\
\text { USA }^{26}\end{array}$ & $\mathrm{~B} / \mathrm{b}$ & $17-39$ & $\mathrm{f}$ & 110 & 1535.0 & 57.7 & 169.0 & 8.9 & $\mathrm{~B}$ \\
\hline & & & $20-39$ & $\mathrm{~m}$ & 200 & 1796.0 & 66.0 & 195.0 & 10.0 & $\mathrm{~B}$ \\
\hline & & & $20-39$ & $\mathrm{f}$ & 199 & 1661.0 & 61.0 & 177.0 & 8.0 & B \\
\hline Bolstad et al (2001) & Norway & $\mathrm{A} / \mathrm{a}$ & $20-29$ & $\mathrm{~m}$ & NA & 1793.0 & 64.0 & 194.0 & 10.0 & B \\
\hline Bolstad et al. (2001) & Norway & $\mathrm{A} / \mathrm{a}$ & $20-29$ & $\mathrm{f}$ & NA & 1663.0 & 61.0 & 177.0 & 9.0 & B \\
\hline & & & $30-39$ & $\mathrm{~m}$ & NA & 1799.0 & 68.0 & 195.0 & 10.0 & B \\
\hline & & & & $\mathrm{f}$ & NA & 1660.0 & 61.0 & 177.0 & 8.0 & $\mathrm{~B}$ \\
\hline Imrhan (2003) & Texas $^{27}$ & $\mathrm{E} / \mathrm{e}$ & $22-32$ & $\mathrm{~m}$ & 17 & 1732.0 & 70.0 & 189.0 & 12.0 & $\mathrm{~B}$ \\
\hline Imrhan (1999) & Texas $^{27}$ & $\mathrm{E} / \mathrm{e}$ & $\begin{array}{c}21,1- \\
50,3 \\
\end{array}$ & $\mathrm{f}$ & 19 & 1618.0 & 90.0 & 172.0 & 7.7 & $\mathrm{~B}$ \\
\hline Bylund and Burström & Sweden & $\mathrm{D} / \mathrm{a}$ & $20-23$ & $\mathrm{~m}$ & 20 & 1800.0 & 55.0 & 178.0 & 10.0 & B \\
\hline$(2006)$ & Sweden & $\mathrm{D} / \mathrm{a}$ & $20-28$ & $\mathrm{f}$ & 20 & 1670.0 & 53.0 & 161.0 & 8.0 & $\mathrm{~B}$ \\
\hline
\end{tabular}


Tab. 1. Complete table of applied population samples - hand and height measurements (continued).

\begin{tabular}{|c|c|c|c|c|c|c|c|c|c|c|}
\hline \multirow[b]{2}{*}{ Study } & \multirow[b]{2}{*}{ state } & \multirow{2}{*}{$\begin{array}{c}\text { measuring } \\
\text { instruments } \\
(\mathrm{H} / \mathrm{HL})\end{array}$} & \multirow[b]{2}{*}{ age } & \multirow[b]{2}{*}{$\operatorname{sex}$} & \multirow[b]{2}{*}{$\mathbf{N}$} & \multicolumn{2}{|c|}{ height } & \multicolumn{3}{|c|}{ hand lenght } \\
\hline & & & & & & mean & sd & mean & sd & side \\
\hline \multirow{14}{*}{ Sadeghi et al. (2015) } & \multirow{14}{*}{ Iran } & \multirow{14}{*}{$\mathrm{B} / \mathrm{b}$} & \multirow{14}{*}{$20-65$} & $\mathrm{~m}$ & 2969 & 1720.0 & 76.3 & 188.0 & 11.7 & B \\
\hline & & & & $\mathrm{f}$ & 751 & 1585.0 & 63.2 & 173.0 & 9.7 & B \\
\hline & & & & $\mathrm{m}$ & 420 & 1715.0 & NA & 192.0 & NA & B \\
\hline & & & & $\mathrm{f}$ & 100 & 1579.0 & NA & 176.0 & NA & B \\
\hline & & & & $\mathrm{m}$ & 22 & 1742.0 & NA & 192.0 & NA & B \\
\hline & & & & $\mathrm{f}$ & 20 & 1576.0 & NA & 177.0 & NA & B \\
\hline & & & & $\mathrm{m}$ & 1682 & 1730.0 & NA & 189.0 & NA & B \\
\hline & & & & $\mathrm{f}$ & 340 & 1584.0 & NA & 171.0 & NA & B \\
\hline & & & & $\mathrm{m}$ & 80 & 1711.0 & NA & 190.0 & NA & B \\
\hline & & & & $\mathrm{f}$ & 30 & 1608.0 & NA & 176.0 & NA & B \\
\hline & & & & $\mathrm{m}$ & 105 & 1739.0 & NA & 191.0 & NA & B \\
\hline & & & & $\mathrm{f}$ & 27 & 1578.0 & NA & 177.0 & NA & B \\
\hline & & & & $\mathrm{m}$ & 660 & 1693.0 & NA & 183.0 & NA & B \\
\hline & & & & $\mathrm{f}$ & 234 & 1590.0 & NA & 170.0 & NA & $\mathrm{B}$ \\
\hline \multirow{2}{*}{ Shahida et al. (2015) } & \multirow{2}{*}{ Malaysia } & \multirow{2}{*}{$\mathrm{B} / \mathrm{b}$} & $60-79$ & $\mathrm{~m}$ & 56 & 1611.0 & 5.0 & 183.0 & 1.0 & B \\
\hline & & & $60-82$ & $\mathrm{f}$ & 56 & 1499.0 & 5.3 & 170.0 & 0.8 & $\mathrm{~B}$ \\
\hline \multirow{2}{*}{ Ali and Arslan (2009) } & \multirow{2}{*}{ Turkey } & \multirow{2}{*}{$\mathrm{E} / \mathrm{e}$} & \multirow{2}{*}{ over 20} & $\mathrm{~m}$ & 2263 & 1708.0 & 81.0 & 189.0 & 14.0 & B \\
\hline & & & & $\mathrm{f}$ & 1942 & 1598.0 & 76.0 & 167.0 & 10.0 & $\mathrm{~B}$ \\
\hline \multirow{2}{*}{ Hu et al. (2007) } & \multirow{2}{*}{ China } & & $65,2-85,1$ & $\mathrm{~m}$ & 50 & 1655.0 & 54.3 & 179.0 & 8.1 & B \\
\hline & & $\mathrm{A} / \mathrm{a}$ & $65-80,7$ & $\mathrm{f}$ & 58 & 1526.0 & 69.3 & 168.0 & 8.1 & $\mathrm{~B}$ \\
\hline Motamedzade et al. (2007) & Iran & & $15-82$ & $\mathrm{~m}$ & 224 & 1590.0 & & 182.0 & 9.0 & B \\
\hline & Iran & $\mathrm{E} / \mathrm{a}$ & $15-82$ & $\mathrm{f}$ & 638 & 1590.0 & 87.0 & 171.0 & 9.0 & $\mathrm{~B}$ \\
\hline & Australia & $\mathrm{A} / \mathrm{e}$ & $65-92$ & $\mathrm{~m}$ & 33 & 1658.0 & 79.0 & 184.0 & 10.0 & B \\
\hline Kothival and Tettey (2000) & Austrana & A/e & $65-93$ & $\mathrm{f}$ & 138 & 1521.0 & 70.0 & 170.0 & 10.0 & B \\
\hline & $\mathrm{UK}^{28}$ & $E / e$ & NA & $\mathrm{m}$ & NA & 1640.0 & 77.0 & 180.0 & 11.0 & B \\
\hline & Un & $\mathrm{L} / \mathrm{C}$ & NA & $\mathrm{f}$ & $\mathrm{NA}$ & 1515.0 & 70.0 & 165.0 & 10.0 & $\mathrm{~B}$ \\
\hline & & & $20-52$ & $\mathrm{~m}$ & 10 & 1645.2 & 48.2 & 184.5 & 8.1 & B \\
\hline Mamansarı and Salokhe (1996) & Tha1land & $\mathrm{A} / \mathrm{e}$ & $25-55$ & $\mathrm{f}$ & 10 & 1519.3 & 67.8 & 151.5 & 11.2 & $\mathrm{~B}$ \\
\hline & & & $18-25$ & $\mathrm{~m}$ & 221 & 1825.0 & 76.2 & 191.0 & 10.3 & B \\
\hline & & & $10-2 J$ & $\mathrm{f}$ & 101 & 1689.0 & 68.6 & 175.0 & 8.9 & B \\
\hline & & & $26-40$ & $\mathrm{~m}$ & 168 & 1825.0 & 78.2 & 194.0 & 10.4 & B \\
\hline Bures et al. (2015) & Czech & & & $\mathrm{f}$ & 91 & 1681.0 & 62.1 & 177.0 & 7.7 & B \\
\hline Bures et al. (2015) & Republic & $\mathrm{A} / \mathrm{a}$ & $41-60$ & $\mathrm{~m}$ & 166 & 1791.0 & 66.1 & 193.0 & 8.0 & B \\
\hline & & & $41-00$ & $\mathrm{f}$ & 179 & 1651.0 & 55.8 & 176.0 & 7.3 & B \\
\hline & & & 61,65 & $\mathrm{~m}$ & 19 & 1768.0 & 42.7 & 189.0 & 8.8 & B \\
\hline & & & $01-03$ & $\mathrm{f}$ & 50 & 1634.0 & 67.5 & 173.0 & 9.0 & $\mathrm{~B}$ \\
\hline & Ching & & $18-60$ & $\mathrm{~m}$ & 11164 & 1678.0 & NA & 183.0 & NA & B \\
\hline & Clinta & & $18-55$ & $\mathrm{f}$ & 11150 & 1570.0 & NA & 171.0 & NA & B \\
\hline & Janan & & $18-59$ & $\mathrm{~m}$ & 12100 & 1690.0 & NA & 182.0 & NA & B \\
\hline I in et al $(2004)$ & & $\mathrm{F} / \mathrm{e}$ & & $\mathrm{f}$ & 8600 & 1569.0 & NA & 168.0 & NA & B \\
\hline Lin et al. (2004) & Koreo & $\mathrm{E} / \mathrm{e}$ & $18-50$ & $\mathrm{~m}$ & 2090 & 1707.0 & NA & 189.0 & NA & B \\
\hline & Nored & & $10-59$ & $\mathrm{f}$ & 2014 & 1588.0 & NA & 175.0 & NA & B \\
\hline & Taiwan & & $18-65$ & $\mathrm{~m}$ & 1322 & 1699.0 & NA & 192.0 & NA & B \\
\hline & Tarvan & & & $\mathrm{f}$ & 799 & 1573.0 & NA & 174.0 & NA & B \\
\hline
\end{tabular}




\section{REFERENCES}

Agnihotri, A.K. - Agnihotri, S. - Jeebun, N. - Googoolye, K. (2008): Prediction of stature using hand dimensions. Journal of Forensic and Legal Medicine, 15, 479-482.

Ahmed, A. A. (2013): Estimation of stature from the upper limb measurements of Sudanese adults. Forensic Science International, 228, 178.e1178.e7.

Akhlaghi, M. - Hajibeygi, M. - Zamani, N. - Moradi, B. (2012): Estimation of stature from upper limb anthropometry in Iranian population. Journal of Forensic and Legal Medicine, 19(5), 280-284.

Ali, İ. - Arslan, N. (2009): Estimated anthropometric measurements of Turkish adults and effects of age and geographical regions. International Journal of Industrial Ergonomics, 39(5), 860-865.

Barut, C. - Dogan, A. - Buyukuysal, M. C. (2014): Anthropometric aspects of hand morphology in relation to sex and to body mass in a Turkish population sample. Homo, 65(4), 338-348.

Bolstad, G. - Benum, B. - Rokne, A. (2001): Anthropometry of Norwegian light industry and office workers. Applied Ergonomics, 32(3), 239-246.

Bouabdallah, L. (2012): Anthropometry of Algerian elderly. Work, 41, 54155416.

Bures, M. - Gorner, T. - Sediva, B. (2015): Hand anthropometry of Czech population. In 2015 IEEE International Conference on Industrial Engineering and Engineering Management (IEEM), 1077-1082.

Bylund, S. H. - Burström, L. (2006): The influence of gender, handle size, anthropometric measures, and vibration on the performance of a precision task. International Journal of Industrial Ergonomics, 36(10), 907-914.

Chandra, A. - Chandna, P. - Deswal, S. (2013): Estimation of hand index for male industrial workers of Haryana State (India). International Journal of Engineering, Science and Technology, 5(1), 55-65.

Chandra, A. - Chandna, P. - Deswal, S. - Mishra, R. K. - Kumar, R. (2015): Stature Prediction Model Based On Hand Anthropometry. International Journal of Medical, Health, Biomedical and Pharmaceutical Engineering, 9(2), 201-207.

Chuan, T. K. - Hartono, M. - Kumar, N. (2010): Anthropometry of the Singaporean and Indonesian populations. International Journal of Industrial Ergonomics, 40(6), 757-766.

Danborno, B. - Elukpo, A. (2008): Sexual Dimorphism in Hand and Foot Length, Indices, Stature-ratio and Relationship to Height in Nigerians. The Internet Journal of Forensic Science, 3(1).

Del Prado-Lu, J. L. (2007): Anthropometric measurement of Filipino manufacturing workers. International Journal of Industrial Ergonomics, 37(6), 497-503.

Dewangan, K. N. - Owary, C. - Datta, R. K. (2008): Anthropometric data of female farm workers from north eastern India and design of hand tools of the hilly region. International Journal of Industrial Ergonomics, 38(1), 90-100.

Dewangan, K. N. - Owary, C. - Datta, R. K. (2010): Anthropometry of male agricultural workers of north-eastern India and its use in design of agricultural tools and equipment. International Journal of Industrial Ergonomics, 40(5), 560-573.

Eksioglu, M. (2004): Relative optimum grip span as a function of hand anthropometry. International Journal of Industrial Ergonomics, 34(1), 1-12.

Fallahi, A. A. - Jadidian, A. A. (2011): The Effect of Hand Dimensions, Hand Shape and Some Anthropometric Characteristics on Handgrip Strength in Male Grip Athletes and Non-Athletes. Journal of Human Kinetics, 29, 151-159.

García-Cáceres, R. G. - Felknor, S. - Córdoba, J. E. - Caballero, J. P. - Barrero, L. H. (2012): Hand anthropometry of the Colombian floriculture workers of the Bogota plateau. International Journal of Industrial Ergonomics, 42(2), 183-198.

Geetha, G. N. - Swathi - Athavale, S. A. (2015): Estimation of Stature From Hand and Foot Measurements in a Rare Tribe of Kerala State in India. Journal of Clinical and Diagnostic Research, 9(10), HC01-HC04.

Goswami, R. B. - Thakur, P. S. - Dadu, S. K. - Rastogi, A. K. (2016): Estimation of stature from anthropometry of hand: an interesting autopsy based study in Madhya Pradesh, India. International Journal of Research in Medical Sciences, 4(6), 1873-1878.
Guerra, R. S. - Fonseca, I. - Pichel, F. - Restivo, M. T. - Amaral, T. F. (2014): Hand length as an alternative measurement of height. European Journal of Clinical Nutrition, 68(2), 229-233.

Habib, S. R. - Kamal, N. N. (2010): Stature estimation from hand and phalanges lengths of Egyptians. Journal of Forensic and Legal Medicine, 17(3), $156-160$.

Häger-Ross, C. - Rösblad, B. (2002): Norms for grip strength in children aged 4-16 years. Acta Paediatrica, 91(6), 617-625.

Hamid, S. - Rashid, A. F. - Najeeb, Q. - Hamid, S. - Makdoomi, A. (2015): Association of Hand Length With Height in Medical Students Enrolled in Skims Medical College, India. International Journal of Anatomy and Research, 3(1), 884-888.

Hanson, L. - Sperling, L. - Gard, G. - Ipsen, S. - Vergara, C. O. (2009): Swedish anthropometrics for product and workplace design. Applied Ergonomics, 40(4), 797-806

Hu, H. - Li, Z. - Yan, J. - Wang, X. - Xiao, H. - Duan, J. - Zheng, L. (2007) Anthropometric measurement of the Chinese elderly living in the Beijing area. International Journal of Industrial Ergonomics, 37(4), 303-311.

Ilayperuma, I. - Nanayakkara, G. - Palahepitiya, N. (2009): Prediction of personal stature based on the hand length. Galle Medical Journal, 14(1), $15-18$.

Imrhan, S. N. (1999): The influence of grip width on two-handed grip strengths in females. International Journal of Industrial Ergonomics, 25(2), 187-194.

Imrhan, S. N. (2003) Two-handed static grip strengths in males: the influence of grip width. International Journal of Industrial Ergonomics, 31(5), 303-311.

Imrhan, S. N. - Nguyen, M-T. - Nguyen, N-N (1993): Hand anthropometry of Americans of Vietnamese origin. International Journal of Industrial Ergonomics, 12(4), 281-287.

Ishak, N-I. - Hemy, N. - Franklin, D. (2012): Estimation of stature from hand and handprint dimensions in a Western Australian population. Forensic Science International, 216, 199.e1-199.e7.

Jaiswal, A. (n.d.): Prediction of Stature from hand lengths among Indians. Retrieved from https://www.mecon.nomadit.co.uk

Jasuja, O. P. - Singh, G. (2004): Estimation of stature from hand and phalange length. Journal of Indian Academy of Forensic Medicine, 26(3), 100-106.

Jee, S. - Yun, M. H. (2015): Estimation of stature from diversified hand anthropometric dimensions from Korean population. Journal of Forensic and Legal Medicine, 35, 9-14.

Karmegan, K. - Sapuan, S. M. - Ismail, M. Y. - Ismail, N. - Shamsul Bahri, M. T. - Shuib, S. - Mohana, G. K. - Seetha, P. - Tamil Moli, P. - Hanapi, M. J. (2011): Anthropometric study among adults of different ethnicity in Malaysia. International Journal of the Physical Sciences, 6(4), 777-788.

Kaur, M. - Singh, B. - Mahajan, A. - Khurana, B. S. - Kaur, A. - Batra, A. P. S. (2013): Anthropometric Measurements of Hand Length for Estimation of Stature in North Indians. International Journal of Applied Biology and Pharmaceutical Technology, 4, 251-255.

Kavyashree, A. N. - Bindurani, M. K. - Asha, K. R. (2015): Determination of stature from hand dimensions in Indian population. Journal of International Medicine and Dentistry, 2(3), 209-214.

Khadem, M. M. - Islam, M. A. (2014): Development of anthropometric data for Bangladeshi male population. International Journal of Industrial Ergonomics, 44(3), 407-412.

Klamklay, J. - Sungkhapong, A. - Yodpijit, N. - Patterson, P. (2008): Anthropometry of the southern Thai population. International Journal of Industrial Ergonomics, 38(1), 111-118.

Koley, S. - Kaur, S. P. (2011): Correlations of Handgrip Strength with Selected Hand-Arm-Anthropometric Variables in Indian Inter-university Female Volleyball Players. Asian Journal of Sports Medicine, 2(4), 220-226.

Kornieieva, M. - Elelemi, A. H. (2016): Estimation of Stature from Hand Measurements and Handprints in a Sample of Saudi Population. Arab Journal of Forensic Sciences and Forensic Medicine, 1(3), 289-298.

Kothiyal, K. - Tettey, S. (2000): Anthropometric data of elderly people in Australia. Applied Ergonomics, 31(3), 329-332.

Krishan, K. - Kanchan, T. - DiMaggio, J. A. (2010): A study of limb asymmetry and its effect on estimation of stature in forensic case work. Forensic Science International, 200, 181.e1-181.e5.

Krishan, K. - Kanchan, T. - Sharma, A. (2012): Multiplication factor versus 
regression analysis in stature estimation from hand and foot dimensions. Journal of Forensic and Legal Medicine, 19(4), 211-214.

Krishan, K. - Sharma, A. (2007): Estimation of stature from dimensions of hands and feet in a North Indian population. Journal of Forensic and Legal Medicine, 14(6), 327-332.

Laila, S. Z. H. - Ferdousi, R. - Nurunnobi, A. B. M. - Islam, A. T. M. S. - Holy, S. Z. H. - Yesmin, F. (2009): Anthropometric Measurements of the hand length and their correlation with the Stature of Bengali adult Muslim females. Bangladesh Journal of Anatomy, 7(1), 10-13.

Laulathaphol, P. - Tiensuwan, M. - Riengrojpitak, S. (2013): Estimation of Stature from Hand Measurements in Thais. SDU Research Journal Sciences and Technology, 6(1), 37-47.

Lin, Y.C. - Wang, M. J. - Wang, E. M. (2004): The comparisons of anthropometric characteristics among four peoples in East Asia. Applied Ergonomics, 35(2), 173-178.

Liu, W. C. V, - Sanchez-Monroyb, D. - Pargac, G. (1999): Anthropometry of female maquiladora workers. International Journal of Industrial Ergonomics, 24(3), 273-280.

Mahakizadeh, S. - Moghani-Ghoroghi, F. - Moshkdanian, G. - Mokhtari, T. - Hassanzadeh, G. (2016): The determination of correlation between stature and upper limb and hand measurements in Iranian adults. Forensic Science International, 260, 27-30.

Mamansari, D. U. - Salokhe, V. M. (1996): Static strength and physical work capacity of agricultural labourers in the central plain of Thailand. Applied Ergonomics, 27(1), 53-60.

Mandahawi, N. - Imrhan, S. - Al-Shobaki, S. - Sarder, B. (2008): Hand anthropometry survey for the Jordanian population. International Journal of Industrial Ergonomics, 38(11-12), 966-976.

Mohamed, M. H. (2013): Measurement of Foot and Hand Dimensions and their Correlation with Height in Adult Upper Egyptians. Al_Azhar Assiut Medical Journal, 11(4), 300-318.

Mohammad, Y. A. A. (2005): Anthropometric characteristics of the hand based on laterality and sex among Jordanian. International Journal of Industrial Ergonomics, 35(8), 747-754.

Mokdad, M. (2002): Anthropometric study of Algerian farmers. International Journal of Industrial Ergonomics, 29(6), 331-341.

Molenbroek, J. F. M. (1987): Anthropometry of elderly people in the Netherlands; research and applications. Applied Ergonomics, 18(3), 187-199.

Moorthy, T. N. - Zulkifly, N. R. B. (2014): Regression Analysis for Stature Determination from Hand Anthropometry of Malaysian Malays for Forensic Investigation. Sri Lanka Journal of Forensic Medicine, Science \& Law, 5(2), 8-15.

Motamedzade, M. - Choobineh, A. - Mououdi, M. A. - Arghami, S. (2007): Ergonomic design of carpet weaving hand tools. International Journal of Industrial Ergonomics, 37(7), 581-587.

Nag, A. - Nag, P. K. - Desai, H. (2003): Hand anthropometry of Indian women. The Indian Journal of Medical Research, 117, 260-269.

Nagesh, K. - Shradha, I. - Suma, M. P. - Neeraj, G. - Dileep, K. R. (2014): Prediction of Stature from Hand Length and Foot Length. Journal of Forensic Identification, 64(1), 18-27.

Numan, A. I. - Idris, M. O. - Zirahei, J. V. - Amaza, D. S. - Dalori, M. B. (2013): Prediction of Stature from Hand Anthropometry: A Comparative Study in the Three Major Ethnic Groups in Nigeria. British Journal of Medicine \& Medical Research, 3(4), 1062-1073.

Oria, R. S. - Igiri, A. O. - Egwu, O. A. - Nandi, M. E. (2016): Prediction of stature from hand length and breadth - anthropometric study on an adult Cross River State population. Annals of Bioanthropology, 4(1), 12-16.

Ozaslan, A. - Karadayi, B. - Kolusayin, M. O. - Kaya, A. - Afsin, H. (2012): Predictive role of hand and foot dimensions in stature estimation. Romanian Journal of Legal Medicine, 20(1), 41-46.

Pal, A. - De, S. - Sengupta, P. - Maity, P. - Dhara, P. C. (2016): Estimation of stature from hand dimensions in Bengalee population, West Bengal, India. Egyptian Journal of Forensic Sciences, 6(2), 90-98.

Patel, J. P. - Patel, B. G. - Shah, R. K. - Bhojak, N. R. - Desai, J. N. (2014): Estimation of stature from hand length in Gujarat region. NHL Journal of Medical Sciences, 3(1), 41-44.

Paulis, M. G. (2015): Estimation of stature from handprint dimensions in Egyptian population. Journal of Forensic and Legal Medicine, 34, 55-61.

Rastogi, P. - Nagesh, K. R. - Yoganarasimha, K. (2008): Estimation of stature from hand dimensions of north and south Indians. Legal Medicine, 10(4), 185-189.

Sadeghi, F. - Mazloumi, A. - Kazemi, Z. (2015): An anthropometric data bank for the Iranian working population with ethnic diversity. Applied Ergonomics, 48, 95-103.

Saengchaiya, N. - Bunterngchit, Y. (2004): Hand Anthropometry of Thai female Industrial Workers. The Journal of KMITNB, 14(1), 16-19.

Sanli, S. G. - Kizilkanat, E. D. - Boyan, N. - Ozsahin, E. T. - Bozkir, M. G. - Soames, R. - Erol, H. - Oguz, O. (2005): Stature Estimation Based on Hand Length and Foot Length. Clinical Anatomy, 18, 589-596.

Saxena, S. K. (1984): A study of correlations and estimation of stature from hand length, hand breadth and sole length. Anthropologischer Anzeiger, 42(4), 271-276.

Shahida, M. S. N. - Zawiah, M. D. S. - Case, K. (2015): The relationship between anthropometry and hand grip strength among elderly Malaysians. International Journal of Industrial Ergonomics, 50, 17-25.

Subashri, A. - Thenmozhi, M. S. (2016): Estimation of Stature using Hand Length in South Indian Region. International Journal of Pharmaceutical Sciences Review and Research, 40(1), 52-54.

Sunil - Dikshit, P. C. - Aggrawal, A. - Rani, M. (2005): Estimation of stature from hand length. Journal of Indian Academy of Forensic Medicine, 27(4) 219-221.

Supare, M. S. - Pandit, S. V. - Bagul, A. S. (2015): Estimation of stature from hand length and hand breadth in medical students of Maharashtra, India. International Journal of Health \& Allied Sciences, 4(3), 154-159.

Tandon, R. - Yunus, S. M. - Faruqi, N. A. - Asghar, A. (2016): Measurements of Hand and Foot - A Predictor of Stature in Adult Human Population of Uttar Pradesh. International Journal of Anatomy, Radiology and Surgery, 5(1), 12-15.

Ugbem, L. P. - Godfrey, E. U. - Ojim, E. E. - Ejuiwa, M. C. (2016): Correlation between Height and Selected Anthropometric Parameters of the Upper Limbs of the Efiks People in Cross River State, Nigeria. Journal of Pharmaceutical and Biomedical Sciences, 6(1), 47-50.

Uhrová, P. - Beňuš, R. - Masnicová, S. - Obertová, Z. - Kramárová, D. - Kyselicová, K. - Dörnhöferová, M. - Bodoriková, S. - Neščáková, E. (2015): Estimation of stature using hand and foot dimensions in Slovak adults. Legal Medicine, 17(2), 92-97.

Varu, P. R. - Manvar, P. J. - Mangal, H. M. - Kyada, H. C. - Vadgama, D. K. - Bhuva, S. D. (2015): Determination of stature from hand dimensions. The Journal of Medical Research, 1(3), 104-107.

Visnapuu, M. - Jürimäe, T. (2007): Handgrip Strength and Hand Dimensions in Young Handball and Basketball Players. Journal of Strength and Conditioning Research, 21(3), 923-929.

Vyavahare, R. T. - Kallurkar, S. P. (2016): Anthropometry of male agricultura workers of western India for the design of tools and equipments. International Journal of Industrial Ergonomics, 53, 80-85.

Waghmare, V. - Gaikwad, R. - Herekar, N. (2010): Estimation of the Stature from the Anthropometric Measurement of Hand Length. The Internet Journal of Biological Anthropology, 4(2).

Wakode, N. S. - Wakode, S. L. - Ksheersagar, D. D. - Tajane, V. D. - Jachak, A. N. (2015): Prediction of Stature based on Measurement of Hand Length in Maharashtra Region. Indian Journal of Clinical Anatomy and Physiology, 2(3), 131-135. 


\section{Stature Estimation from the Hand Length: Testing Cross-Population Methods}

\section{Appendix 2}

Tab. 1. Complete table of applied population samples - intercepts and slopes.

\begin{tabular}{|c|c|c|c|c|c|c|c|c|}
\hline study & state & $\begin{array}{c}\text { measuring } \\
\text { instruments } \\
(\mathrm{H} / \mathrm{HL})\end{array}$ & age & $\operatorname{sex}$ & $\mathbf{N}$ & $\mathbf{a}$ & b & side \\
\hline \multirow{2}{*}{ Geetha et al. (2015) } & \multirow{2}{*}{ India } & \multirow{2}{*}{$\mathrm{A} / \mathrm{a}$} & \multirow{2}{*}{$20-30$} & $\mathrm{~m}$ & 100 & 1063.06 & 2.83 & B \\
\hline & & & & $\mathrm{f}$ & 100 & 14.54 & 8.71 & $\mathrm{~B}$ \\
\hline \multirow{4}{*}{ Uhrová et al. (2015) } & \multirow{4}{*}{ Slovakia } & \multirow{4}{*}{$\mathrm{A} / \mathrm{a}$} & \multirow{4}{*}{$18-24$} & \multirow{2}{*}{$\mathrm{m}$} & \multirow{2}{*}{120} & 931.10 & 4.63 & $\mathrm{R}$ \\
\hline & & & & & & 963.10 & 4.45 & $\mathrm{~L}$ \\
\hline & & & & \multirow{2}{*}{$\mathrm{f}$} & \multirow{2}{*}{130} & 846.90 & 4.75 & $\mathrm{R}$ \\
\hline & & & & & & 851.60 & 4.72 & $\mathrm{~L}$ \\
\hline Pal et al. (2016) & India & $\mathrm{A} / \mathrm{a}$ & $20-40$ & $\mathrm{f}$ & 896 & 881.00 & 3.88 & $\mathrm{~B}$ \\
\hline Mahakizadeh et al. (2016) & Iran & $\mathrm{E} / \mathrm{e}$ & $18-25$ & $\mathrm{~m}$ & 146 & 948.11 & 3.74 & $\mathrm{R}$ \\
\hline \multirow{2}{*}{ Paulis (2015) } & \multirow{2}{*}{ Egypt } & \multirow{2}{*}{$\mathrm{A} / \mathrm{d}$} & \multirow{2}{*}{$18-67$} & $\mathrm{~m}$ & 100 & 1095.33 & 3.02 & $\mathrm{R}$ \\
\hline & & & & $\mathrm{f}$ & 91 & 1345.16 & 1.26 & $\mathrm{R}$ \\
\hline \multirow{2}{*}{ Jee and Yun (2015) } & \multirow{2}{*}{ South Korea } & \multirow{2}{*}{$\mathrm{E} / \mathrm{a}$} & $20-70$ & $\mathrm{~m}$ & 167 & 880.51 & 4.45 & $\mathrm{R}$ \\
\hline & & & $20-83$ & $\mathrm{f}$ & 154 & 789.92 & 4.48 & $\mathrm{R}$ \\
\hline \multirow{6}{*}{ Numan et al. (2013) } & \multirow{2}{*}{ Nigeria ${ }^{1}$} & \multirow{6}{*}{$\mathrm{B} / \mathrm{a}$} & \multirow{6}{*}{$18-35$} & $\mathrm{~m}$ & 70 & 784.20 & 4.67 & $\mathrm{R}$ \\
\hline & & & & $\mathrm{f}$ & 64 & 727.90 & 4.75 & $\mathrm{R}$ \\
\hline & \multirow{2}{*}{ Nigeria $^{2}$} & & & $\mathrm{~m}$ & 70 & 631.10 & 5.36 & $\mathrm{R}$ \\
\hline & & & & $\mathrm{f}$ & 68 & 1342.80 & 1.77 & $\mathrm{R}$ \\
\hline & \multirow{2}{*}{ Nigeria $^{3}$} & & & $\mathrm{~m}$ & 70 & 1169.20 & 2.34 & $\mathrm{R}$ \\
\hline & & & & $\mathrm{f}$ & 65 & 1085.20 & 2.88 & $\mathrm{R}$ \\
\hline Ahmed (2013) & Sudan & & & $\mathrm{m}$ & 100 & 1111.70 & 3.34 & $\mathrm{~L}$ \\
\hline Anmed (2013) & Sudan & $\mathrm{A} / \mathrm{a}$ & $25-30$ & $\mathrm{f}$ & 100 & 905.50 & 4.04 & $\mathrm{~L}$ \\
\hline & & & & $\mathrm{m}$ & 224 & 922.01 & 4.15 & $\mathrm{R}$ \\
\hline Ozaslan et al. (2012) & Turkey & $\mathrm{A} / \mathrm{c}$ & $20-51$ & $\mathrm{f}$ & 132 & 1116.56 & 2.80 & $\mathrm{R}$ \\
\hline & & & & $\mathrm{m}$ & 123 & 873.32 & 4.45 & $\mathrm{~L}$ \\
\hline Krishan et al. (2012) & India & $\mathrm{E} / \mathrm{e}$ & $17-20$ & $\mathrm{f}$ & 123 & 845.39 & 4.24 & $\mathrm{~L}$ \\
\hline & & & $19-68$ & $\mathrm{~m}$ & 91 & 697.23 & 5.57 & $\mathrm{R}$ \\
\hline Ishak et al. (2012) & Australia & $\mathrm{A} / \mathrm{a}$ & & & & 667.28 & 5.71 & $\mathrm{~L}$ \\
\hline & Austrana & $\mathrm{A} / \mathrm{d}$ & $18-63$ & $f$ & 110 & 571.35 & 6.06 & $\mathrm{R}$ \\
\hline & & & $18-63$ & $\mathrm{I}$ & 110 & 559.34 & 6.12 & $\mathrm{~L}$ \\
\hline Akhlaohi et al (2012) & Iran & $\mathrm{F} / \mathrm{a}$ & $21-26$ & $\mathrm{~m}$ & 50 & 1159.96 & 3.15 & $\mathrm{~L}$ \\
\hline Akniagni et al. (2012) & Iran & $\mathrm{E} / \mathrm{a}$ & $21-20$ & $\mathrm{f}$ & 50 & 762.79 & 5.01 & $\mathrm{~L}$ \\
\hline Krishan et al (2010) & India & F/e & $18-30$ & $\mathrm{~m}$ & 967 & 1056.32 & 3.64 & $\mathrm{R}$ \\
\hline Krisnan el al. (2010) & India & $\mathrm{E} / \mathrm{e}$ & $18-50$ & $\mathrm{~m}$ & 901 & 1162.43 & 3.06 & $\mathrm{~L}$ \\
\hline & & & & $\mathrm{m}$ & 82 & 577.00 & 6.06 & $\mathrm{R}$ \\
\hline Habib and Kamal (2010) & Eoynt & $\mathrm{A} / \mathrm{a}$ & $18-25$ & $\mathrm{~m}$ & 82 & 634.90 & 5.74 & $\mathrm{~L}$ \\
\hline Habio and Kamal (2010) & Egypt & $\mathrm{A} / \mathrm{a}$ & $18-25$ & $f$ & & 1011.30 & 3.39 & $\mathrm{R}$ \\
\hline & & & & $\mathrm{I}$ & 71 & 901.50 & 4.01 & $\mathrm{~L}$ \\
\hline & Sri Lanka & & $20-23$ & $\mathrm{~m}$ & 140 & 1037.32 & 3.49 & B \\
\hline llayperuma et al. (2009) & Sri Lanka & $\mathrm{B} / \mathrm{a}$ & $20-23$ & $\mathrm{f}$ & 118 & 936.89 & 3.63 & B \\
\hline
\end{tabular}

Overview of used studies. M - male, $\mathrm{f}$ - female, $\mathrm{N}$ - number of individuals, NA - not available, side - side of hand: R - right, L - left, B - both hands. Measuring instruments $\mathrm{H}$ (height): A - stadiometer; anthropometer; B - standing height measuring instrument and unspecified tool from anthropometric sets/kits; $\mathrm{C}$ - other tools: measuring tape, meter gauge, body meter, meter rule, metal tape; D - verbal information; E - NA. Measuring instruments HL (hand length: a caliper, sliding caliper, Vernier caliper, digital caliper, spreading caliper, anthropometric rod Compass, segmometer, small metallic anthropometer, L - shaped scale; $\mathrm{b}$ - unspecified tool from anthropometric sets; $\mathrm{c}$ - standard measuring tape, calibrated non stretch tape; $\mathrm{d}$ - hand length was measured from: hand prints, outlines of the hand, 2D scans (flatbed scanner), 3D scans (3D digitizer ISOTRAK II); e - NA. ${ }^{1}-$ ethnicity Hausa, ${ }^{2}-$ ethnicity Igbo, ${ }^{3}-$ ethnicity Yoruba, ${ }^{4}-$ north Indians, ${ }^{5}$ - south Indians, ${ }^{6}$ - Jat Sikh: a peasant tribe or caste of northern India and erstwhile Punjab now part of Pakistan, ${ }^{7}-$ south Indians, ${ }^{8}-$ north Indians, ${ }^{9}$ - hand prints. 
Tab. 1. Complete table of applied population samples - intercepts and slopes (continued).

\begin{tabular}{|c|c|c|c|c|c|c|c|c|}
\hline study & state & $\begin{array}{c}\text { measuring } \\
\text { instruments } \\
(\mathrm{H} / \mathrm{HL})\end{array}$ & age & sex & $\mathbf{N}$ & $\mathbf{a}$ & b & side \\
\hline \multirow{8}{*}{ Rastogi et al. (2008) } & \multirow{4}{*}{ India $^{4}$} & \multirow{8}{*}{$\mathrm{A} / \mathrm{a}$} & \multirow{8}{*}{$20-30$} & \multirow{2}{*}{$\mathrm{m}$} & \multirow{2}{*}{120} & 813.43 & 4.78 & $\mathrm{R}$ \\
\hline & & & & & & 802.41 & 4.84 & $\mathrm{~L}$ \\
\hline & & & & \multirow{2}{*}{$\mathrm{f}$} & \multirow{2}{*}{100} & 802.00 & 4.61 & $\mathrm{R}$ \\
\hline & & & & & & 833.56 & 4.43 & $\mathrm{~L}$ \\
\hline & \multirow{4}{*}{ India $^{5}$} & & & \multirow{2}{*}{$\mathrm{m}$} & \multirow{2}{*}{110} & 690.06 & 5.47 & $\mathrm{R}$ \\
\hline & & & & & & 743.80 & 5.19 & $\mathrm{~L}$ \\
\hline & & & & \multirow{2}{*}{$\mathrm{f}$} & \multirow{2}{*}{170} & 830.44 & 4.45 & $\mathrm{R}$ \\
\hline & & & & & & 844.32 & 4.37 & $\mathrm{~L}$ \\
\hline \multirow{2}{*}{ Agnihotri et al. (2008) } & \multirow{2}{*}{ Mauritius } & \multirow{2}{*}{$\mathrm{A} / \mathrm{a}$} & \multirow{2}{*}{$18-30$} & $\mathrm{~m}$ & 125 & 948.35 & 4.19 & $\mathrm{~L}$ \\
\hline & & & & $\mathrm{f}$ & 125 & 744.04 & 4.95 & $\mathrm{~L}$ \\
\hline \multirow{6}{*}{ Krishan and Sharma (2007) } & & & & & & 896.30 & 4.31 & $\mathrm{R}$ \\
\hline & & & & $\mathrm{m}$ & 123 & 886.30 & 4.37 & $\mathrm{~L}$ \\
\hline & Indi & $A /$ & 170 & & & 882.43 & 4.39 & B \\
\hline & & A $/ \mathfrak{a}$ & $17-20$ & & & 812.20 & 4.43 & $\mathrm{R}$ \\
\hline & & & & $\mathrm{f}$ & 123 & 845.40 & 4.24 & $\mathrm{~L}$ \\
\hline & & & & & & 813.14 & 4.42 & $\mathrm{~B}$ \\
\hline & & & & $m$ & 20 & 695.13 & 5.22 & $\mathrm{R}$ \\
\hline Jacuin and Sinot $(2004)$ & India/Dakictan 6 & 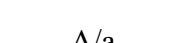 & $18-60$ & $\mathrm{~m}$ & 30 & 847.42 & 4.49 & $\mathrm{~L}$ \\
\hline Jasuja and Singin (2004) & India/Pakistan & $\mathrm{A} / \mathrm{a}$ & $18-60$ & $f$ & 30 & 1309.54 & 1.61 & $\mathrm{R}$ \\
\hline & & & & $\mathrm{t}$ & 30 & 1300.35 & 1.66 & $\mathrm{~L}$ \\
\hline & & & & $\mathrm{m}$ & 72 & 1251.50 & 2.69 & $\mathrm{R}$ \\
\hline Patel et al (2014) & India & $\mathrm{F} / \mathrm{a}$ & $18-22$ & $\mathrm{~m}$ & 12 & 1256.70 & 2.67 & $\mathrm{~L}$ \\
\hline Patel et al. (2014) & Inara & $\mathrm{E} / \mathrm{a}$ & $18-22$ & $f$ & 78 & 1106.40 & 2.95 & $\mathrm{R}$ \\
\hline & & & & & & 1106.90 & 2.95 & $\mathrm{~L}$ \\
\hline Jaiswal (N D) & India & $\mathrm{A} / \mathrm{a}$ & $18-31$ & $\mathrm{~m}$ & 112 & 948.35 & 4.19 & $\mathrm{~L}$ \\
\hline & & & & $\mathrm{f}$ & 103 & 744.04 & 4.95 & $\mathrm{~L}$ \\
\hline & & & & $m$ & 50 & 1094.65 & 3.42 & $\mathrm{R}$ \\
\hline J aulathanhol et al (2013) & Thailand & $\Delta / 9$ & $18-26$ & & & 1048.19 & 3.68 & $\mathrm{~L}$ \\
\hline Lauratnapnor el al. (2013) & inalrand & $\mathrm{A} / \mathrm{d}$ & $18-20$ & $f$ & 50 & 845.87 & 4.50 & $\mathrm{R}$ \\
\hline & & & & & & 913.18 & 4.12 & $\mathrm{~L}$ \\
\hline Chikhalkar et al (2010) & India & $\mathrm{B} / \mathrm{e}$ & $19-23$ & $\mathrm{~m}$ & 147 & 116893 & 267 & $\mathrm{~B}$ \\
\hline & & & & $\mathrm{f}$ & 153 & & & \\
\hline Vor & Ind & $A$ & 1705 & $\mathrm{~m}$ & 200 & 1309.00 & 2.398 & $\mathrm{~L}$ \\
\hline Kaur et al. (2013) & India & $\mathrm{A} / \mathrm{a}$ & $1 /-25$ & $\mathrm{f}$ & 200 & 1604.10 & 0.027 & $\mathrm{~L}$ \\
\hline & & & & & & 575.44 & 5.67 & $\mathrm{R}$ \\
\hline & & & $22-86$ & $\mathrm{~m}$ & 250 & 580.37 & 5.69 & $\mathrm{~L}$ \\
\hline Cosuromi 1 (2016) & Indio & $C / \rho_{0}$ & & & & 557.19 & 5.80 & B (avg.) \\
\hline Goswam1 et al. (2016) & India & $\mathrm{C} / \mathrm{a}$ & & & & 597.11 & 5.83 & $\mathrm{R}$ \\
\hline & & & $22-70$ & $\mathrm{f}$ & 250 & 651.29 & 5.56 & $\mathrm{~L}$ \\
\hline & & & & & & 763.25 & 5.39 & B (avg.) \\
\hline Oria et o $(2016)$ & Nigeria & $\mathrm{C} / \mathrm{a}$ & 1845 & $\mathrm{~m}$ & 540 & 1064.63 & 3.19 & B \\
\hline Oria et al. (2016) & Nigeria & $\mathrm{C} / \mathrm{a}$ & $18-45$ & $\mathrm{f}$ & 510 & 918.79 & 3.88 & B \\
\hline & & & & & & 856.64 & 4.68 & $\mathrm{R}$ \\
\hline & & & & $\mathrm{m}$ & 94 & 970.14 & 4.05 & $\mathrm{~L}$ \\
\hline Wol-odo ot o1 (2015) & India & $\Delta /$ & 1725 & & & 916.34 & 4.35 & B (avg.) \\
\hline Wakode et al. (2015) & Inora & $\mathrm{A} / \mathrm{d}$ & $1 /-25$ & & & 767.27 & 4.84 & $\mathrm{R}$ \\
\hline & & & & $\mathrm{f}$ & 106 & 810.02 & 4.54 & L \\
\hline & & & & & & 793.77 & 4.69 & B (avg.) \\
\hline & & & & $m$ & & 855.17 & 4.45 & $\mathrm{R}$ \\
\hline Voruet o1 $(2015)$ & India & $\mathrm{C} / \mathrm{a}$ & 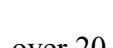 & $\mathrm{m}$ & 100 & 929.72 & 4.08 & $\mathrm{~L}$ \\
\hline varu el al. (2015) & Inora & $\mathrm{c} / \mathrm{d}$ & over $\angle 0$ & $f$ & 100 & 864.30 & 3.88 & $\mathrm{R}$ \\
\hline & & & & & & 904.32 & 3.66 & $\mathrm{~L}$ \\
\hline
\end{tabular}


Tab. 1. Complete table of applied population samples - intercepts and slopes (continued).

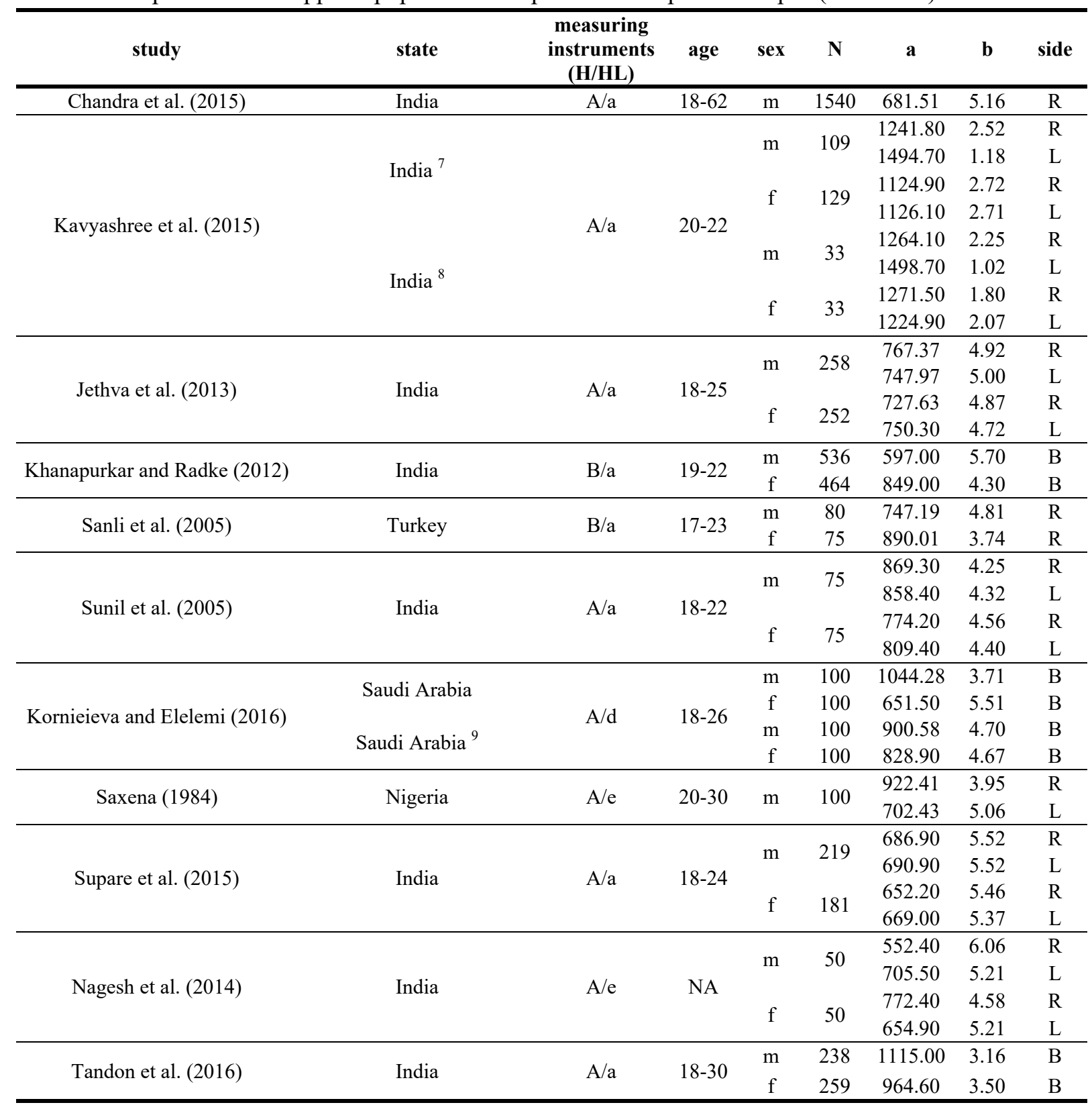




\section{REFERENCES}

Agnihotri, A. K. - Agnihotri, S. - Jeebun, N. - Googoolye, K. (2008): Prediction of stature using hand dimensions. Journal of Forensic and Legal Medicine, 15(8), 479-482.

Ahmed, A. A. (2013): Estimation of stature from the upper limb measurements of Sudanese adults. Forensic Science International, 228, 178.e1178.e7.

Akhlaghi, M. - Hajibeygi, M. - Zamani, N. - Moradi, B. (2012): Estimation of stature from upper limb anthropometry in Iranian population. Journal of Forensic and Legal Medicine, 19(5), 280-284.

Chandra, A. - Chandna, P. - Deswal, S. - Mishra, R. K. - Kumar, R. (2015): Stature Prediction Model Based On Hand Anthropometry. International Journal of Medical, Health, Biomedical and Pharmaceutical Engineering, 9(2), 201-207.

Chikhalkar, B. G. - Mangaonkar, A. A. - Nanandkar, S. D. - Peddawad, R. G. (2010): Estimation of Stature from Measurements of Long Bones, Hand and Foot Dimensions. Journal of Indian Academy of Forensic Medicine, 32(4), 329-331.

Geetha, G. N. - Swathi - Athavale, S. A. (2015): Estimation of Stature From Hand and Foot Measurements in a Rare Tribe of Kerala State in India. Journal of Clinical and Diagnostic Research, 9(10), HC01-HC04.

Goswami, R. B. - Thakur, P. S. - Dadu, S. K. - Rastogi, A. K. (2016): Estimation of stature from anthropometry of hand: an interesting autopsy based study in Madhya Pradesh, India. International Journal of Research in Medical Sciences, 4(6), 1873-1878.

Habib, S. R. - Kamal, N. N. (2010): Stature estimation from hand and phalanges lengths of Egyptians. Journal of Forensic and Legal Medicine, 17(3), $156-160$.

Ilayperuma, I. - Nanayakkara, G. - Palahepitiya, N. (2009): Prediction of personal stature based on the hand length. Galle Medical Journal, 14(1), $15-18$.

Ishak, N-I. - Hemy, N. - Franklin, D. (2012): Estimation of stature from hand and handprint dimensions in a Western Australian population. Forensic Science International, 216, 199.e1-199.e7.

Jaiswal, A. (N. D.): Prediction of Stature from hand lengths among Indians. Retrieved from https://www.mecon.nomadit.co.uk

Jasuja, O. P. - Singh, G. (2004): Estimation of stature from hand and phalange length. Journal of Indian Academy of Forensic Medicine, 26(3), 100-106.

Jee, S. - Yun, M. H. (2015): Estimation of stature from diversified hand anthropometric dimensions from Korean population. Journal of Forensic and Legal Medicine, 35, 9-14.

Jethva, N. - Patel, S. M. - Vora, R. - Parmar, G. (2013): Estimation Of Stature From Hand Length In Living Subjects Of Gujarat Region. National Journal of Integrated Research in Medicine, 4(4), 57-60.

Kaur, M. - Singh, B. - Mahajan, A. - Khurana, B. S. - Kaur, A. - Batra, A. P. S. (2013): Anthropometric Measurements of Hand Length for Estimation of Stature in North Indians. International Journal of Applied Biology and Pharmaceutical Technology, 4(2), 251-255.

Kavyashree, A. N. - Bindurani, M. K. - Asha, K. R. (2015): Determination of stature from hand dimensions in Indian population. Journal of International Medicine and Dentistry, 2(3), 209-214.

Khanapurkar, S. - Radke, A. (2012): Estimation of stature from the measurement of foot length, hand length and head length in Maharashtra region. Indian Journal of Basic \& Applied Medical Research, 1(2), 77-85.

Kornieieva, M. - Elelemi, A. H. (2016): Estimation of Stature from Hand Measurements and Handprints in a Sample of Saudi Population. Arab Journal of Forensic Sciences and Forensic Medicine, 1(3), 289-298.

Krishan, K. - Kanchan, T. - DiMaggio, J. A. (2010): A study of limb asymmetry and its effect on estimation of stature in forensic case work. Forensic Science International, 200, 181.e1-181.e5.

Krishan, K. - Kanchan, T. - Sharma, A. (2012): Multiplication factor versus regression analysis in stature estimation from hand and foot dimensions. Journal of Forensic and Legal Medicine, 19(4), 211-214.
Krishan, K. - Sharma, A. (2007): Estimation of stature from dimensions of hands and feet in a North Indian population. Journal of Forensic and Legal Medicine, 14(6), 327-332.

Laulathaphol, P. - Tiensuwan, M. - Riengrojpitak, S. (2013): Estimation of Stature from Hand Measurements in Thais. SDU Research Journal Sciences and Technology, 6(1), 37-47.

Mahakizadeh, S. - Moghani-Ghoroghi, F. - Moshkdanian, G. - Mokhtari, T. - Hassanzadeh, G. (2016): The determination of correlation between stature and upper limb and hand measurements in Iranian adults. Forensic Science International, 260, 27-30.

Nagesh, K. - Shradha, I. - Suma, M. P. - Neeraj, G. - Dileep, K. R. (2014): Prediction of Stature from Hand Length and Foot Length. Journal of Forensic Identification, 64(1), 18-27.

Numan, A. I. - Idris, M. O. - Zirahei, J. V. - Amaza, D. S. - Dalori, M. B. (2013): Prediction of Stature from Hand Anthropometry: A Comparative Study in the Three Major Ethnic Groups in Nigeria. British Journal of Medicine \& Medical Research, 3(4), 1062-1073.

Oria, R. S. - Igiri, A. O. - Egwu, O. A. - Nandi, M. E. (2016): Prediction of stature from hand length and breadth - anthropometric study on an adult Cross River State population. Annals of Bioanthropology, 4(1), 12-16.

Ozaslan, A. - Karadayi, B. - Kolusayin, M. O. - Kaya, A. - Afsin, H. (2012) Predictive role of hand and foot dimensions in stature estimation. Romanian Journal of Legal Medicine, 20(1), 41-46.

Pal, A. - De, S. - Sengupta, P. - Maity, P. - Dhara, P. C. (2016): Estimation of stature from hand dimensions in Bengalee population, West Bengal, India. Egyptian Journal of Forensic Sciences, 6(2), 90-98.

Patel, J. P. - Patel, B. G. - Shah, R. K. - Bhojak, N. R. - Desai, J. N. (2014): Estimation of stature from hand length in Gujarat region. NHL Journal of Medical Sciences, 3(1), 41-44.

Paulis, M. G. (2015): Estimation of stature from handprint dimensions in Egyptian population. Journal of Forensic and Legal Medicine, 34, 55-61.

Rastogi, P. - Nagesh, K. R. - Yoganarasimha, K. (2008): Estimation of stature from hand dimensions of north and south Indians. Legal Medicine, 10(4), 185-189.

Sanli, S. G. - Kizilkanat, E. D. - Boyan, N. - Ozsahin, E. T. - Bozkir, M. G. - Soames, R. - Erol, H. - Oguz, O. (2005): Stature Estimation Based on Hand Length and Foot Length. Clinical Anatomy, 18, 589-596.

Saxena, S. K. (1984): A study of correlations and estimation of stature from hand length, hand breadth and sole length. Anthropologischer Anzeiger, 42(4), 271-276.

Sunil - Dikshit, P. C. - Aggrawal, A. - Rani, M. (2005): Estimation of stature from hand length. Journal of Indian Academy of Forensic Medicine, 27(4), 219-221.

Supare, M. S. - Pandit, S. V. - Bagul, A. S. (2015): Estimation of stature from hand length and hand breadth in medical students of Maharashtra, India. International Journal of Health \& Allied Sciences, 4(3), 154-159.

Tandon, R. - Yunus, S. M. - Faruqi, N. A. - Asghar, A. (2016): Measurements of Hand and Foot - A Predictor of Stature in Adult Human Population of Uttar Pradesh. International Journal of Anatomy, Radiology and Surgery, 5(1), 12-15.

Uhrová, P. - Beňuš, R. - Masnicová, S. - Obertová, Z. - Kramárová, D. - Kyselicová, K. - Dörnhöferová, M. - Bodoriková, S. - Neščáková, E. (2015): Estimation of stature using hand and foot dimensions in Slovak adults. Legal Medicine, 17(2), 92-97.

Varu, P. R. - Manvar, P. J. - Mangal, H. M. - Kyada, H. C. - Vadgama, D. K. - Bhuva, S. D. (2015): Determination of stature from hand dimensions. The Journal of Medical Research, 1(3), 104-107.

Wakode, N. S. - Wakode, S. L. - Ksheersagar, D. D. - Tajane, V. D. - Jachak, A. N. (2015): Prediction of Stature based on Measurement of Hand Length in Maharashtra Region. Indian Journal of Clinical Anatomy and Physiology, 2(3), 131-135. 